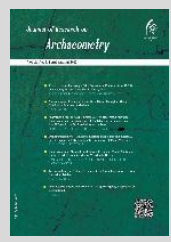

Original Paper

\title{
A Review of the Applications of Synchrotron Radiation in Archaeological Sciences
}

\author{
Masoud Abdollahi' ${ }^{1}$, Saeid Asgharizadeh ${ }^{2 *}$, Mehdi Razani ${ }^{3}$ \\ ${ }^{1}$ MA in Photonics-Electronics, Department of Photonics-Electronics, University of Tabriz, IRAN \\ 2 Assistant Professor, Department of Photonics-Electronics, University of Tabriz, IRAN \\ 2 Assistant Professor, Faculty of Applied Arts, Tabriz Islamic Art University, Tabriz, IRAN
}

Received: $28 / 12 / 2019$

Accepted: 04/07/2020

\begin{abstract}
The scientific research regarding investigation, characterization and protection of the archeological specimens is manifested through a notable participation of multidisciplinary subjects and experts, scientists and archeometrists. One of the main principals which are considered by archaeometrists in the study of the precious specimens is the utilizing nondestructive methods. As an example, in synchrotrons, parameters such as the high photon flux, the small source size and the low divergence attained make it a very efficient source for a range of advanced spectroscopy and imaging techniques, adapted to the heterogeneity and great complexity of the materials under study. The use of synchrotron radiation techniques to study cultural heritage and archaeological materials has undergone a steep increase over the past 10-15 years. The techniques mainly have been focused on are: X-ray fluorescence (XRF), X-ray absorption (XAS), X-ray tomography microscopy (XTM), $\mathrm{X}$-ray diffraction (XRD), and Fourier transform-infrared spectroscopy (FT-IR) analyses. Among these, XRF spectroscopy is based on the detection of characteristic X-rays emitted. Impinging Xrays on an atom creates inner electron vacancy in it, where the excited atom returns to its ground state, the fluorescing photon is emitted. The energy of this photon is the difference in energy between the vacancy and the electronic state of the electron filling the vacancy. Analysis of the XRF spectra includes identification of the elements from the fluorescence spectra observed. On the other hand, XAS (or X-ray Absorption Spectroscopy) relies on the absorption of X-rays by atoms of the materials in the vicinity of the absorption edge of one of its constituting elements. This technique gives chemical information on the coordination sphere of the absorber. In X-ray tomography, a set of radiographs are taken and used to reconstruct a 3D morphology of the studied object. With two procedure, the obtained 3D morphology corresponds to what is measured in the radiography: X-ray absorption contrast where the image formed on the detector is described assuming an straight trajectory for each photon when the density of the transversed matter modulates its intensity on the detector; where the main effect of the matter is refraction and the absorption is negligible, X-ray phase contrast plays role while the photon direction changes as it travels inside the material. Diffraction takes place whenever the wavelength of the interacting wave is comparable with a length scale of a periodic structure. Therefore, the analysis of X-ray diffraction patterns gives information about the atomic and molecular structure of matter. For amorphous systems, however, the absence of an ordered structure limits outcomes of the XRD technique. Nevertheless, it gives significant information on average interatomic or intermolecular distances. Infrared spectroscopy is based on a transition in the vibrational state of the molecules when the
\end{abstract}

*Corresponding author: asgharizadeh@tabrizu.ac.ir

Copyright (C) 2020, the Authors / This open-access article is published under the terms of the Creative Commons Attribution-NonCommercial 4.0 International License which permits Share (copy and redistribute the material in any medium or format) and Adapt (remix, transform, and build upon the material) under the Attribution-

NonCommercial .terms 
incident photon is absorbed. The energy of this photon is a characteristic of the nature of each vibration, involving a single bond or chemical group in the molecule. In this research, how synchrotron radiation, identified with super brilliant and parallel micro x-rays, can be applied to characterize archeological specimens is presented, and then, some results by which the advantages of using the synchrotron radiation technique over the prior ones can be stressed, noticeably, will be reasoned.

Keywords: X-ray, XRD, Synchrotron, Archaeometry 


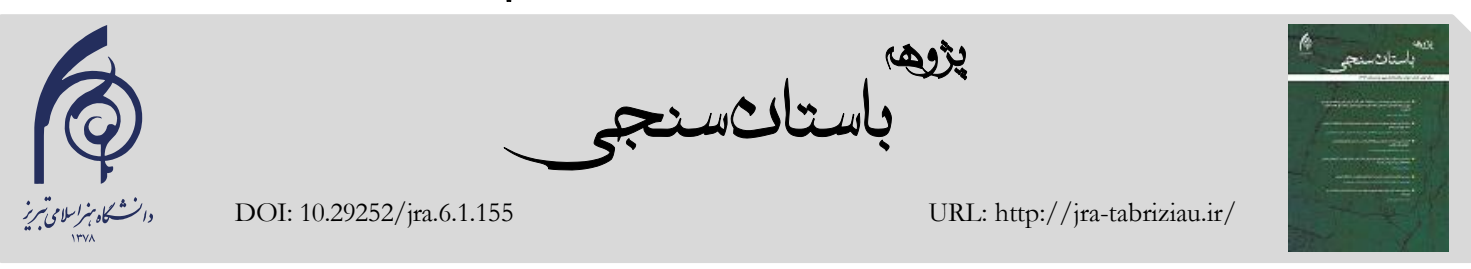

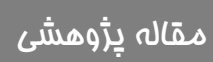

(1)

مرورى بر كاربردهاى تابش سينكروترون در

علوم باستانشناختى

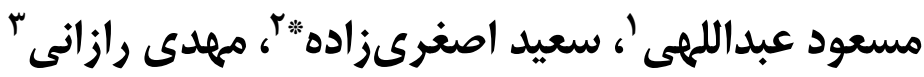

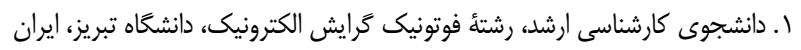

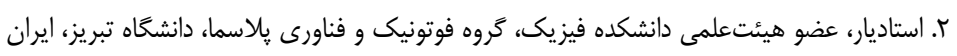

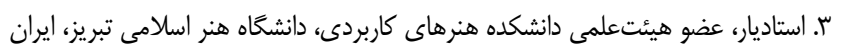

تحقيقات علمى باهدف بررسى، شناسايى و حفاظت از يافتههاى باستانشناسى و هنرى، بر اساس رويكردى قابلتأمـل از اشـتراى

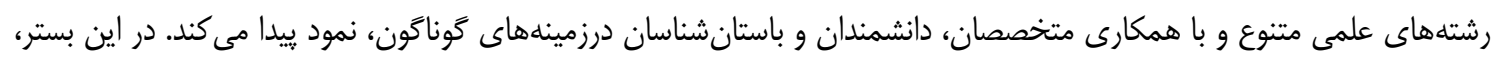

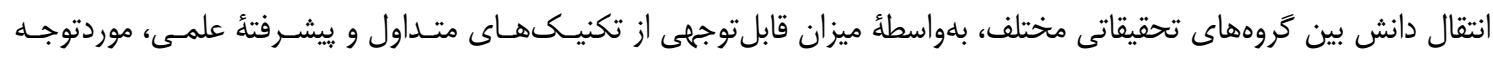

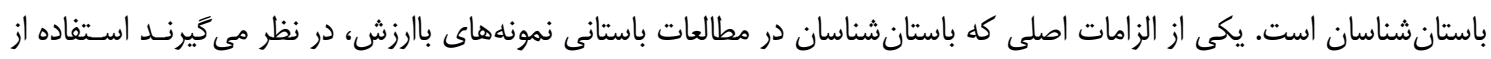

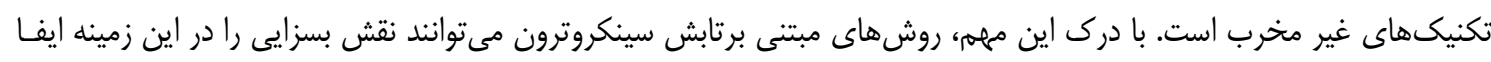

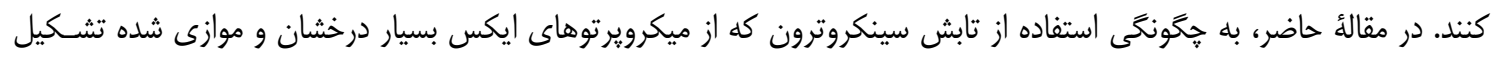

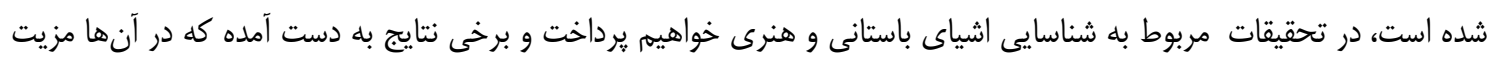

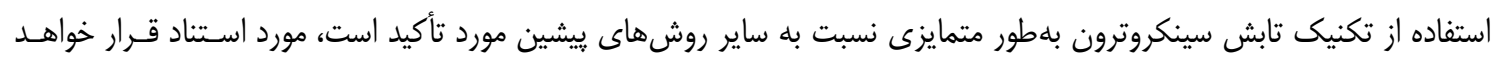

وازَّان كليدى: سينكروترون، يرتوايكس، باستانشناسى، يراش يرتوايكس، يراكندگى' يرتوايكس

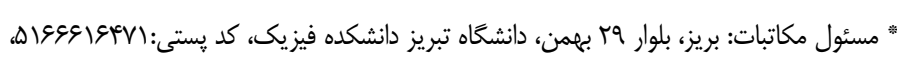

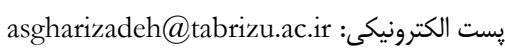
C) حق نشر متعلق به نويسنده(كان) است و نويسنده تحت مجوز Creative Commons Attribution License به مجله اجازه مى دهد مقاله خاب شده

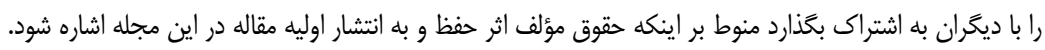


شتابدهندة خطـى سـوق داده مسىشـوند. در مرحلــأ دو،

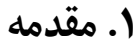

الكترونها به جندين گروه تقسيم و دستهبندى مى شعوند و

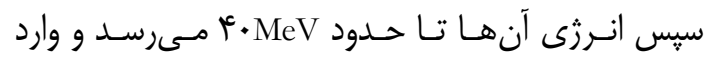
تقويت كننده مىشود. مرحلة سه، شامل تقويـت و افـز ايش

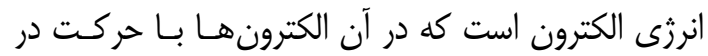

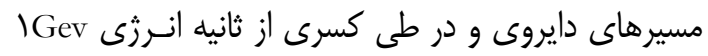

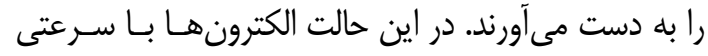

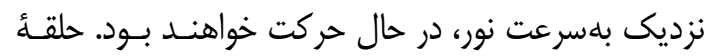

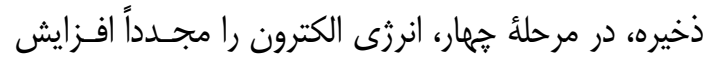

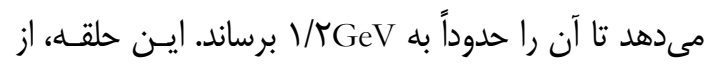

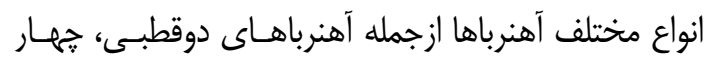

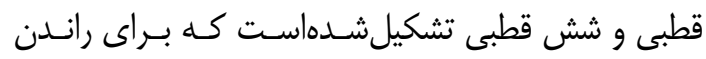

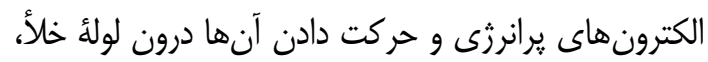

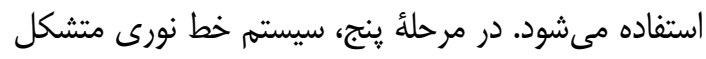

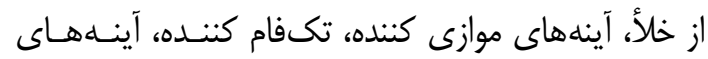

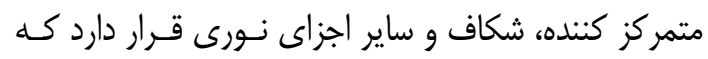

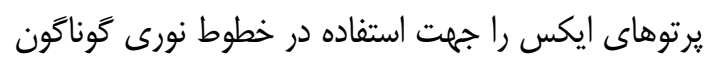
و براى مقاصد مختلف علمى، در اختيار استفاده كنــدكان

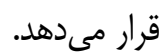

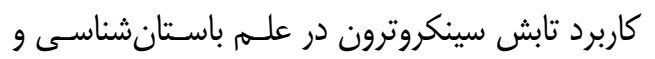
ميراثفرهنكى كه با همكارى و مشورت باستـان شناسـان،

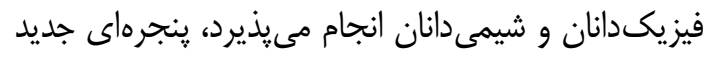

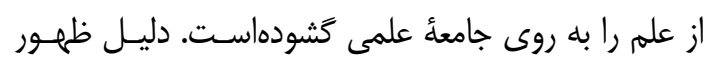

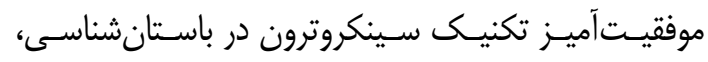

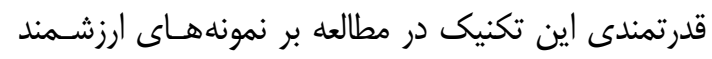

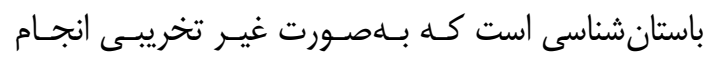

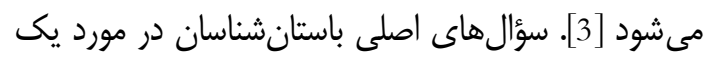
شىء قديمى، مىتواند شامل موارد زير باشد:

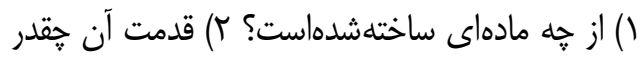

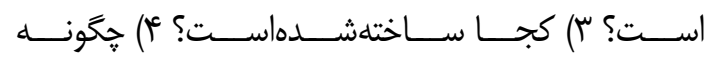

$$
\text { تخريبشدهاست؟ ه) مكانيسم تخريب آن جيست؟ }
$$

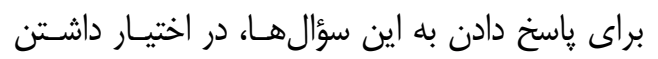

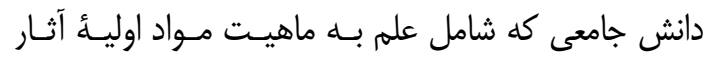

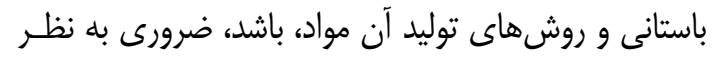

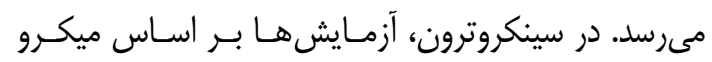

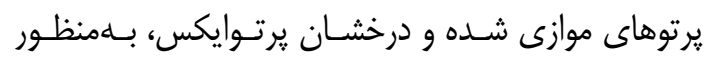
تابش سـينكروترونى (Synchrotron radiation) نخسـتين

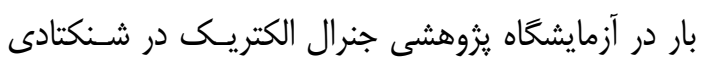

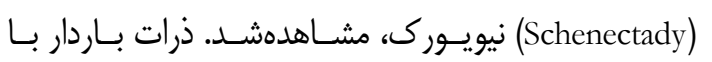

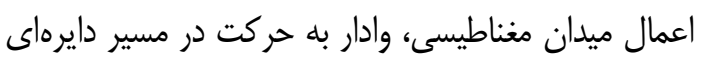

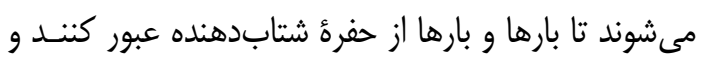

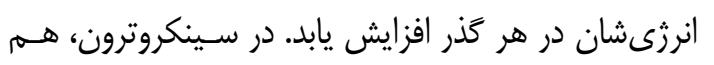

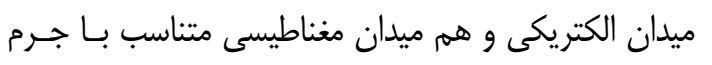

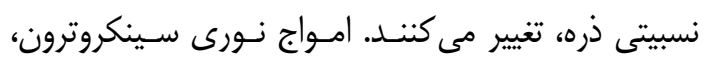

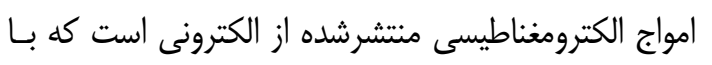

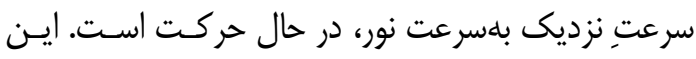

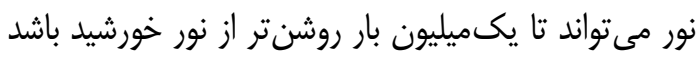

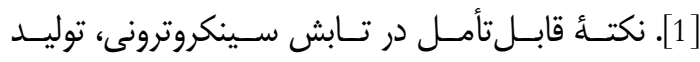

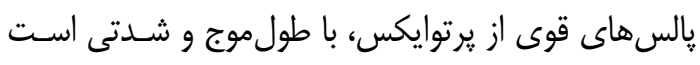

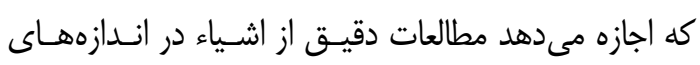
مختلف از سلولهاى انسانى، ويروسها و اتمها گرفتـه تـا

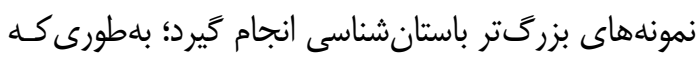
با روش هاى ديخر مطالعـات، بــا ايـن دقـت قابـل انجـام

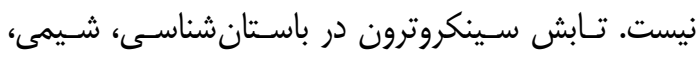

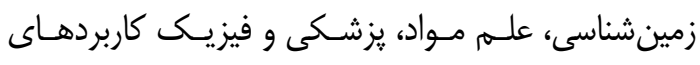

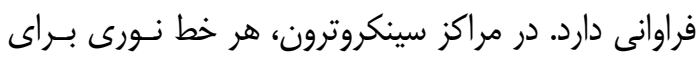

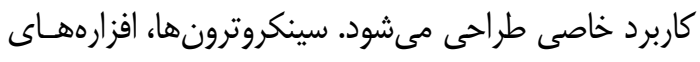

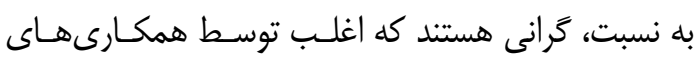

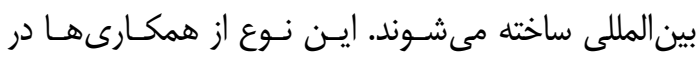
يروزههاى مربوط به ساخت و بهرهبردارى سينكروترونهـا از مزاياى مهم آن بلهساب مى آيند [1].

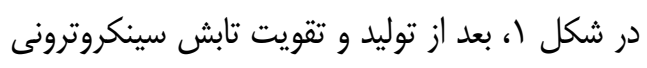

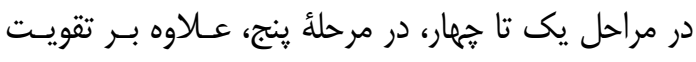

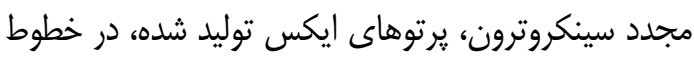
نورى مختلف، براى مقاصد گوناگون مـورد اسـتفاده قـرار

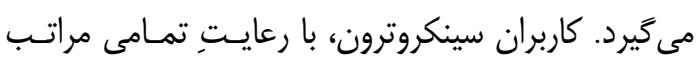
حفاظت در برابر يرتوهاى يرانرزى توليدشده، قادر به انجام

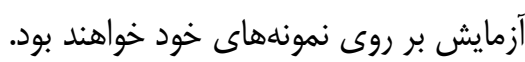

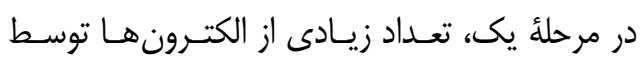

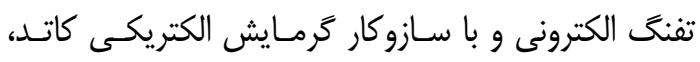

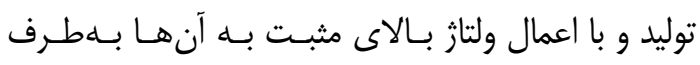




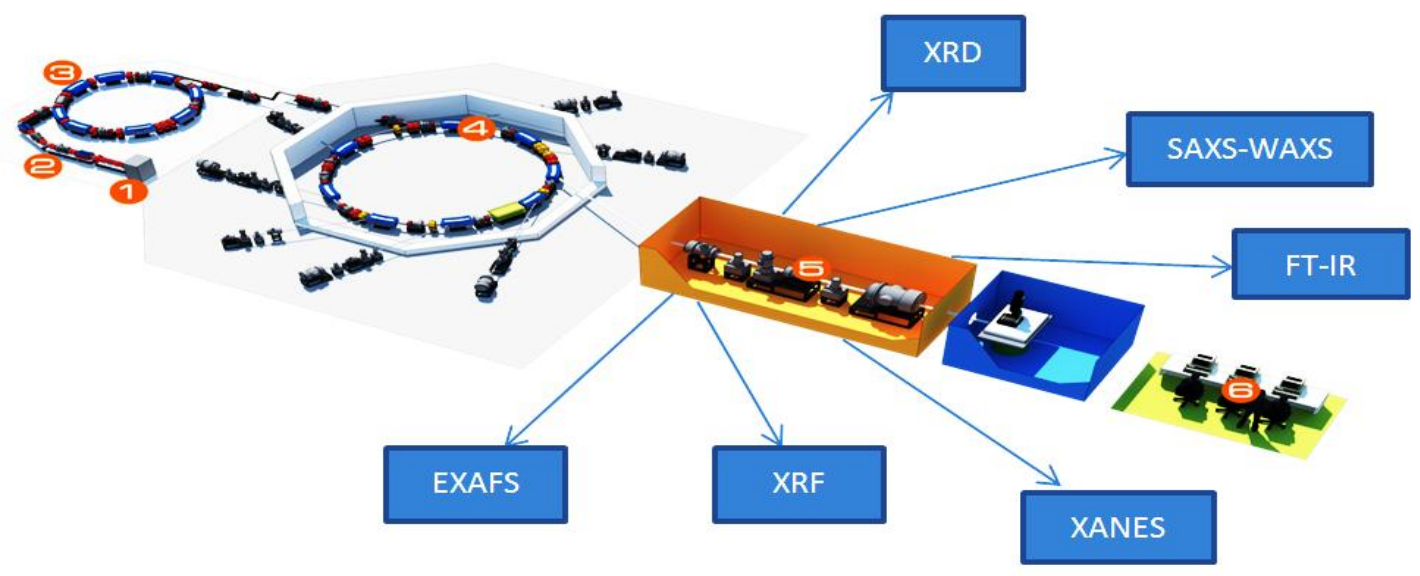

شكل (: طرحواره توليد امواج سينكروترون و استخراج اطلاعات از آن [2]

Fig: 1: Synchrotron wave generation and data extraction [2]

تشديد شـده سـاختار ريـز Extended X-ray ] EXAFS) تشــا ([absorption fine structure س. اطلاعات در مورد حضور و ماهيت فازهاى بلورى

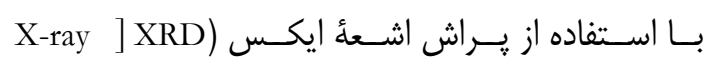
[diffraction

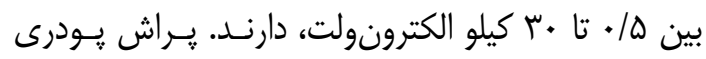

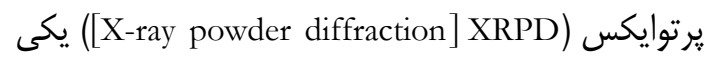

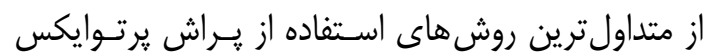

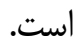

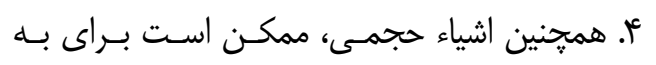

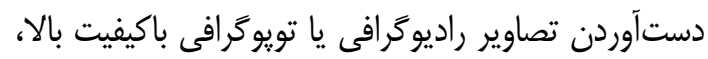

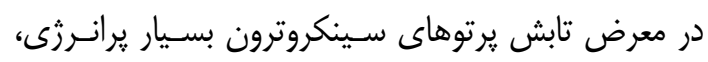
قرار گيرند تا ساختار داخلى آنان آشكارسازى شود.

\section{ז. تاريخجهُ سينكروترون}

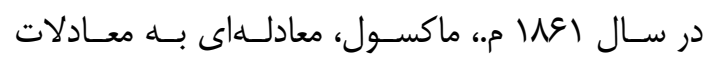

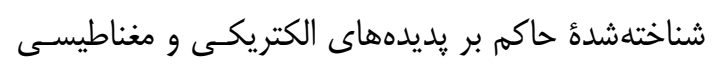

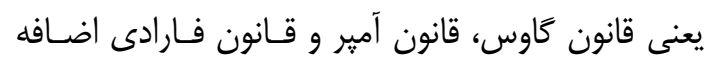

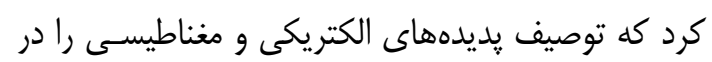

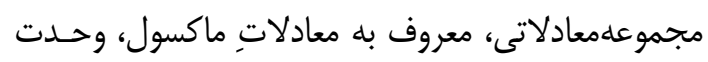

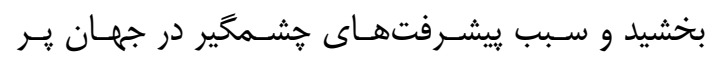

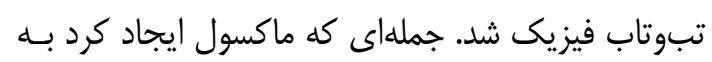

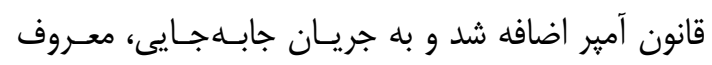

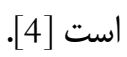

ايجـاد دادههـاى يــراش، اسيكتروسـكويى و تصـويرى بــاـ قدرت تفكيك منحصربلهفرد مورداستفاده قرار مى

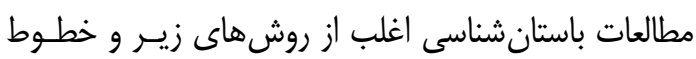
نورى متناظر استفاده مىشود [3]:

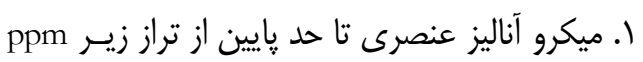

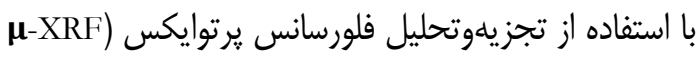
[Micro X-ray fluorescence] اصولى مشـابه بـا فلورسـانس يرتـوايكس (X-ray ] XRF

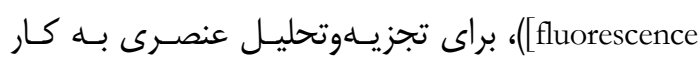

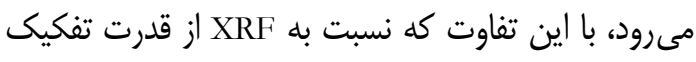

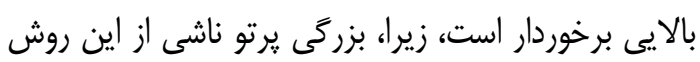

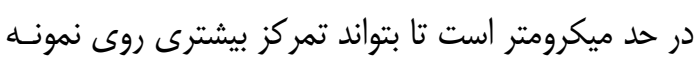

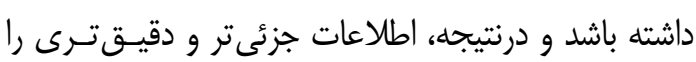

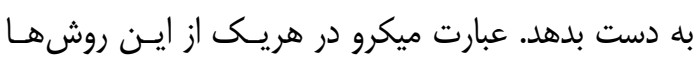

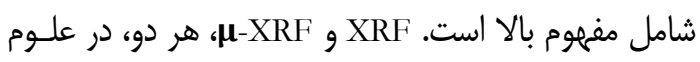
باستانشناسى كاربرد دارند. r. رديابى محلى تركيب شيميايى اجزاى يك شـى

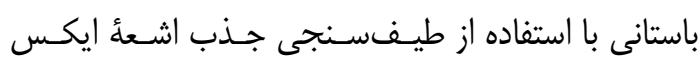
ب[X-ray absorption spectroscopy] XAS)

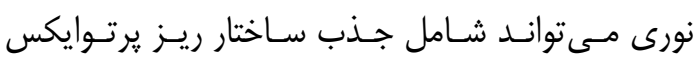

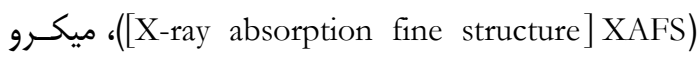

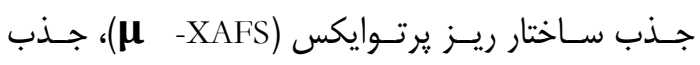

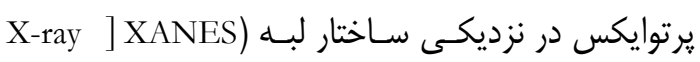

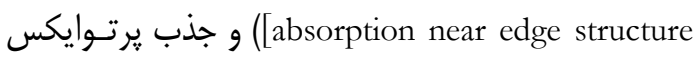


خاموش كنيه، زيرا در لولأ آن، جرقهاى مشاهده كرده بود.

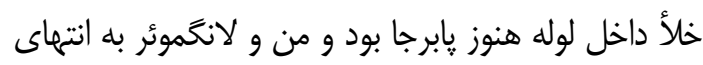

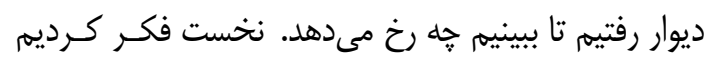

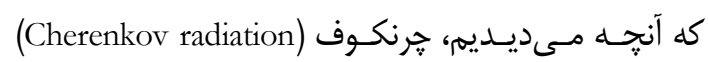

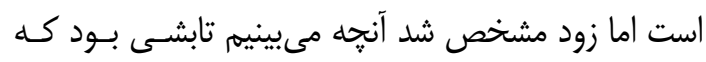

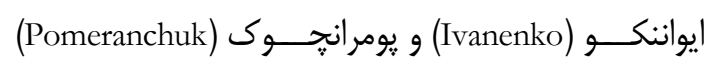
ييشيينى كرده بودنده، نام تابش سينكروترون از همينجا

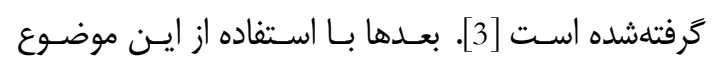

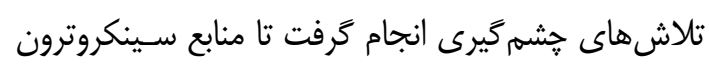

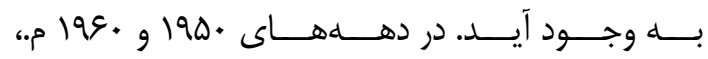
شتابدهندهــاى ذرات، در ابتــا بــراى تحقيـق در مـورد

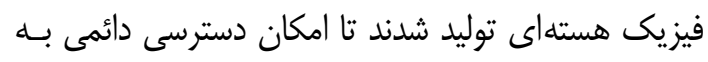

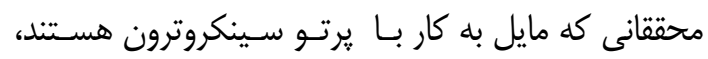

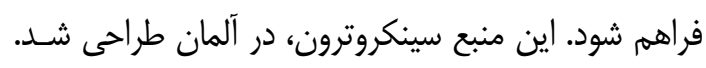

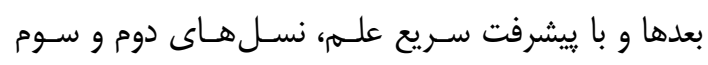

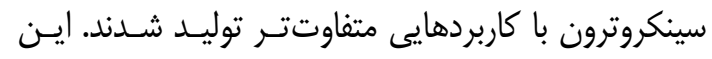

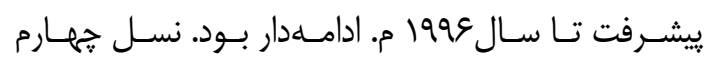

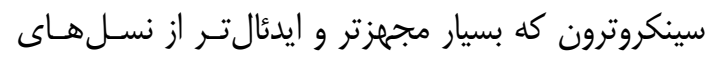

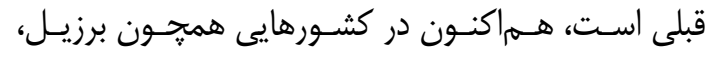

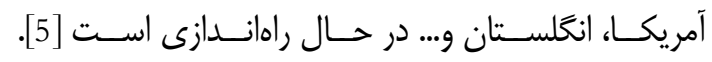
همجِنين طرح سزامى (مركـز تـابش سـينكروترون بـراى

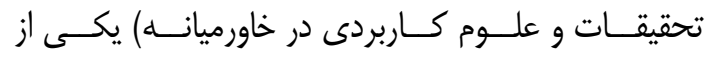

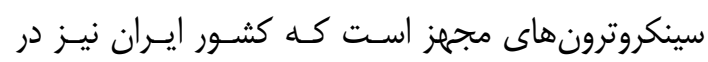

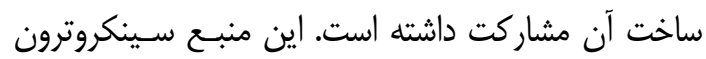

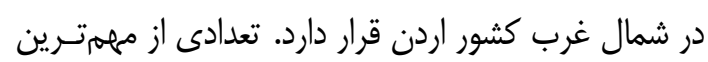
مراكز سينكروترون جهان در جدول آورد آده شده است.

\section{" ا. فيزيك سينكروترون}

شتاب دادن ذرات باردار، باعث تابش الكترومغناطيسى آنان مى شود. عبارت تابش سينكروترونى، اغلب، زمانى استفاده

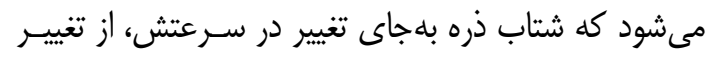

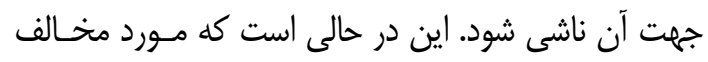

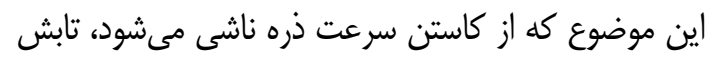

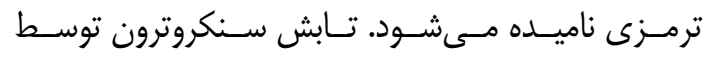

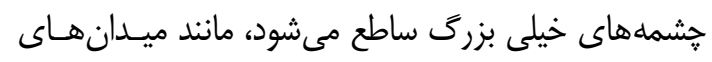

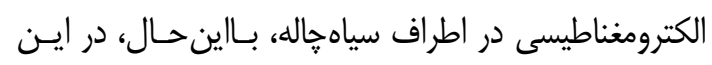

$$
\begin{aligned}
& \nabla \cdot \boldsymbol{E}=\frac{\rho}{\varepsilon_{0}} \\
& \nabla . \boldsymbol{B}=0 \\
& \nabla \times \boldsymbol{E}=-\frac{\partial \boldsymbol{B}}{\partial t} \\
& \nabla \times \boldsymbol{B}=\mu_{0} \boldsymbol{J}+\mu_{0} \varepsilon_{0} \frac{\partial \boldsymbol{E}}{\partial t}
\end{aligned}
$$
الكتريكى و مغناطيسى هستند. مجنَالى بار الكتريكىى كذردهى الكتريكى خلأ و $\mu_{0}$ ضريب تراوايسى مغناطيسى

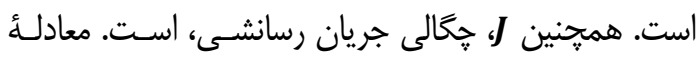

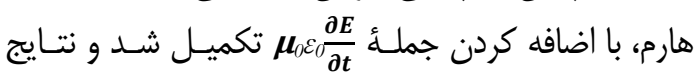
حيرتانكيزى را به شرح زير، براى علم فيزيك به ارمنـان

آورد: - (آحيرت

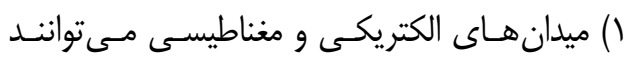

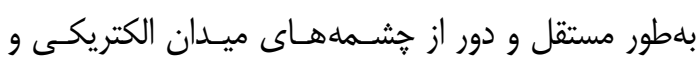

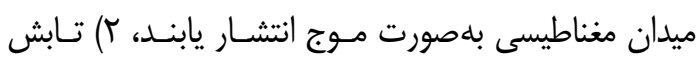

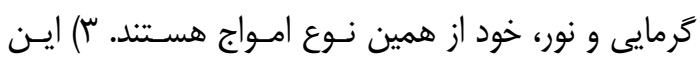

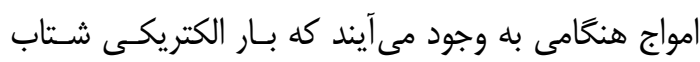

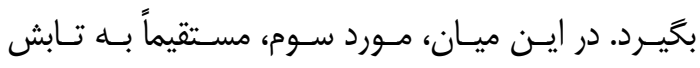

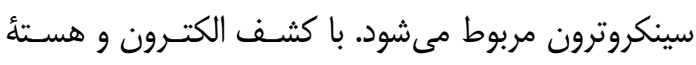

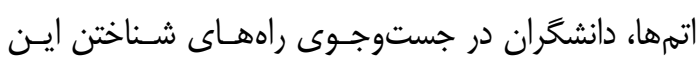

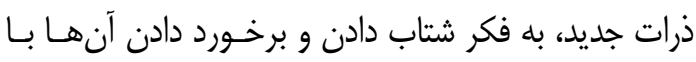
يكديكر و يا باهدفهاى شناختهشده، افتادند. اين كار ابتـــا

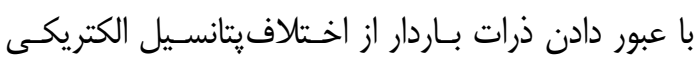

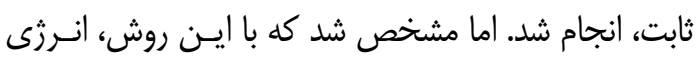

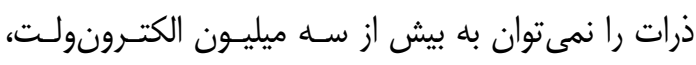

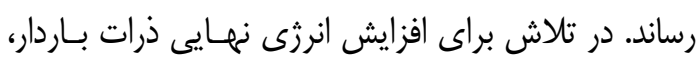

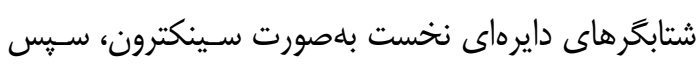

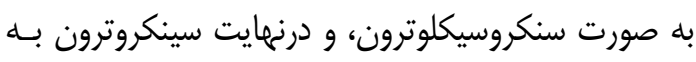
بار آمدند. فرانك الــر (Frank Elder)، فرانكـاتول كَورئيج Robert (Anatole Gurewitsch) و هرب يولاك (Langmuir

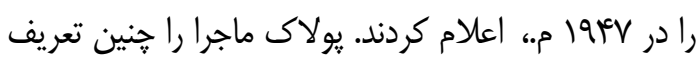

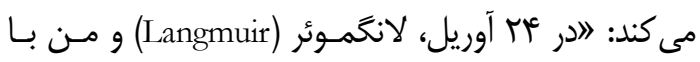

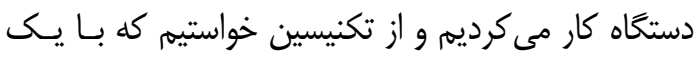
آشكارساز، فضاى اطراف محافظ بتنى را مورد بازرسى قرار

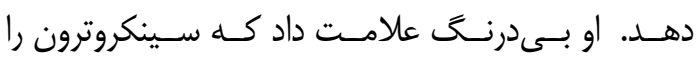

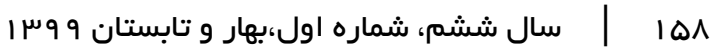




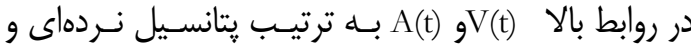

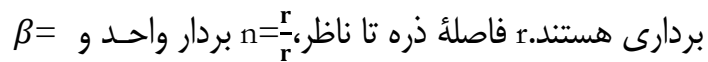

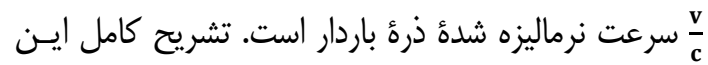
يتانسيل ها بسيار طولانى و فراتـر از محـدودهُ ايــن مقالـه

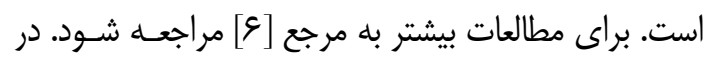

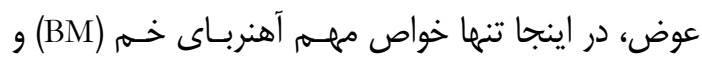

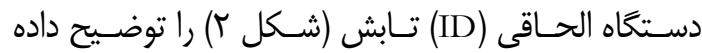

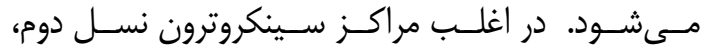

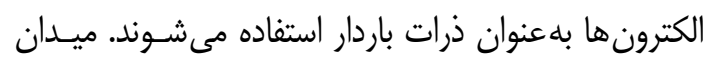

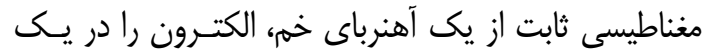

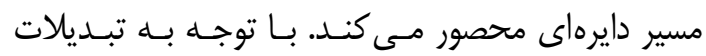

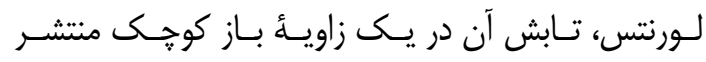

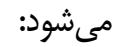

$$
\Theta \approx \sin \Theta=\frac{1}{\gamma}
$$

$$
\text { با برگ خريد لورنتس ز: }
$$

$$
\gamma=\frac{1}{\sqrt{1-\beta^{2}}}=\frac{\mathrm{e}}{\mathrm{m}_{\mathrm{e}} \mathrm{c}^{2}}
$$

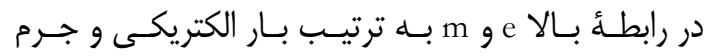

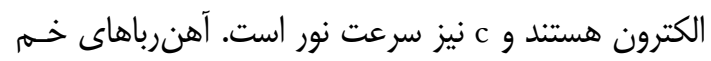
كنندهُ مسير، طيف يهنى را كه حـول فركانس مشخصـه،

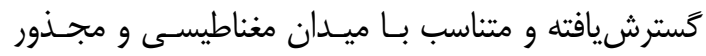
انرزى الكترون است، منتشر مى كنند. قدرت تابش (P)، به مجـذور انـرزى الكتـــــن (E) و
زمينه ما تنها يرتو توليدشده در تأسيسات سينكروترون را أ

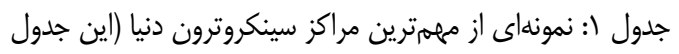

اطلاعات عمومى نويسندًان از مراكز سينكروترون است)

\begin{tabular}{|c|c|}
\hline 1 & $\begin{array}{l}\text { مركز سينكروترون آلبا، اسيانيا } \\
\text { ALBA synchrotron facility, Spain }\end{array}$ \\
\hline 2 & $\begin{array}{l}\text { مركز سينكروترون ساسكاجوان، كانادان } \\
\text { Canadian light source facility,Canada }\end{array}$ \\
\hline 3 & $\begin{array}{l}\text { مركز سينكروترون ارويا، فرانسه } \\
\text { European synchrotron radiation } \\
\text { facility,France }\end{array}$ \\
\hline 4 & $\begin{array}{l}\text { مركز سينكروترون الترا، ايتاليا } \\
\text { Elettra synchrotron center , Italy }\end{array}$ \\
\hline 5 & $\begin{array}{l}\text { مركز سينكروترون يترا، آلمان } \\
\text { PETRA synchrotron center, Germany }\end{array}$ \\
\hline 6 & $\begin{array}{l}\text { مركز سينكروترون داياموند، انخَلستان } \\
\text { Diamond synchrotron center, England }\end{array}$ \\
\hline 7 & $\begin{array}{l}\text { مركز سينكروترون استراليا، استراليا } \\
\text { Australian Synchrotron center, Australia }\end{array}$ \\
\hline
\end{tabular}

Table 1: Some of the important synchrotron radiation facilities in the world

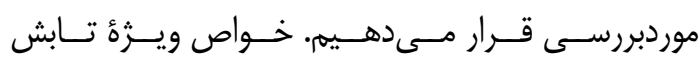

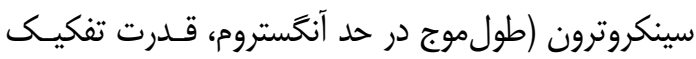
بالا و...) ناشى از تبديلات لورنتس است كـه در آن نـاظر،

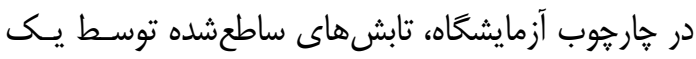

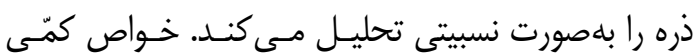
تابش، توسط يتانسيل لينار -ويشرت توصيفشده است:

$$
\begin{aligned}
& \mathrm{V}(\mathrm{t})=\frac{\mathrm{e}}{4 \pi \epsilon_{0}}\left(\frac{1}{\mathrm{r}\left(\mathrm{t}^{\prime}\right)\left(1-\mathrm{n}\left(\mathrm{t}^{\prime}\right) \cdot \beta\left(\mathrm{t}^{\prime}\right)\right)}\right) \\
& \mathrm{A}(\mathrm{t})=\frac{\mu_{0} \mathrm{e}}{4 \pi}\left(\frac{\beta\left(\mathrm{t}^{\prime}\right) \mathrm{c}}{\mathrm{r}\left(\mathrm{t}^{\prime}\right)\left(1-\mathrm{n}\left(\mathrm{t}^{\prime}\right) \cdot \beta\left(\mathrm{t}^{\prime}\right)\right)}\right)
\end{aligned}
$$

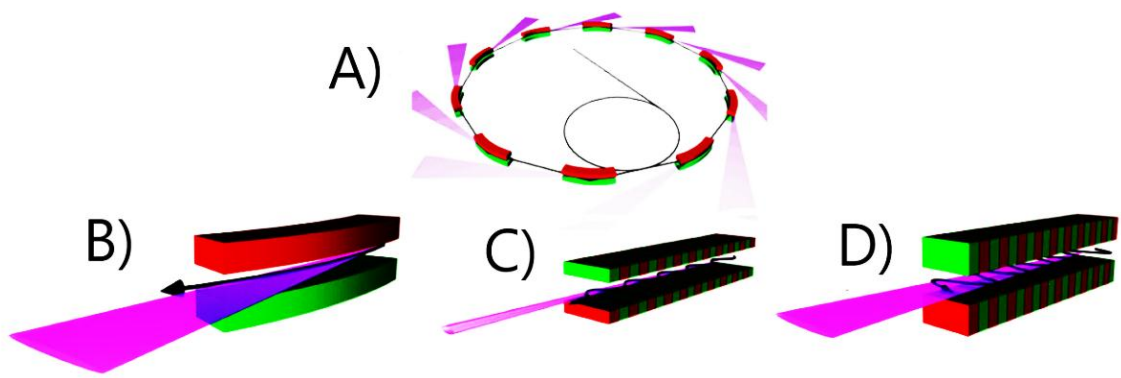

شكل ז: A: مجموعهاى از الكترونهايى كه در يك شتابدهنده خطى و (در بيشتر موارد ) در يك سينكروترون تقويتكنتده، شتاب مى گيرند. از

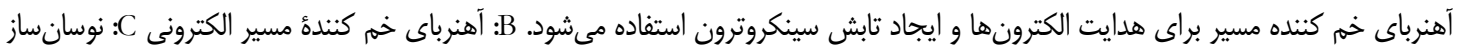

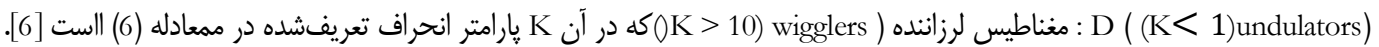

Fig. 2: a) Set of accelerated electrons through a linear accelerator and (in most of the cases) amplifying synchrotron. Bending magnets are used to direct electrons and generate synchrotron radiation, b) magnet to bend the electron trajectory, c) undulator $(K<\mathbf{1})$, d) wigglers $(K>10)$, where $K$ is defined as deviation parameter explained in equation $6[6]$. 
مغناطيس لرزاننده، مسير الكترون، انحراف زيادى يبيدا مسى

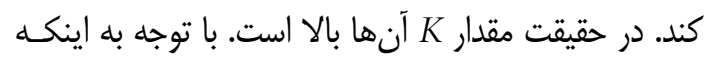

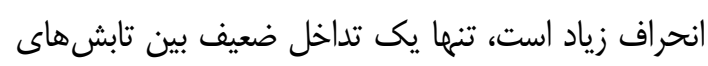

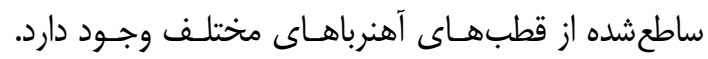

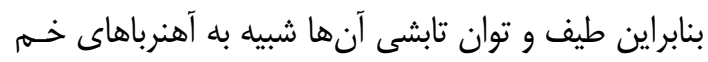
است. درخشندمى يكى از خواص مهم منابع سينكروترون اسـت؛ كه بلهورت زير تعريف مىشود:

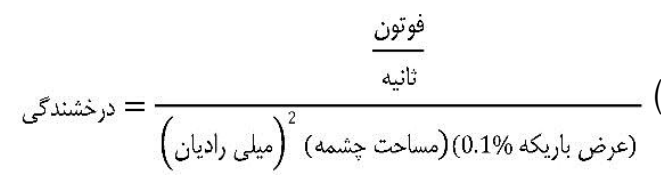

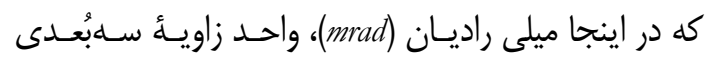

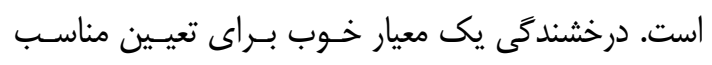

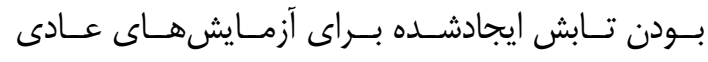

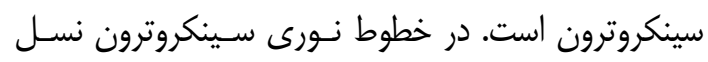

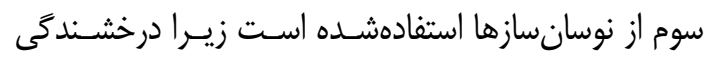

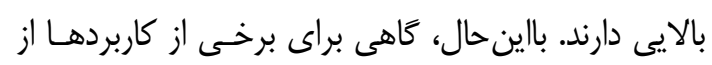

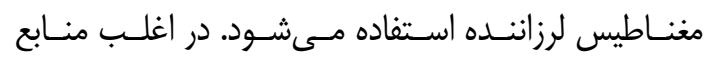

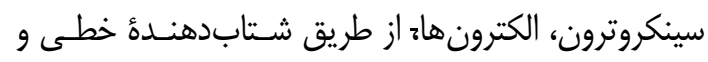

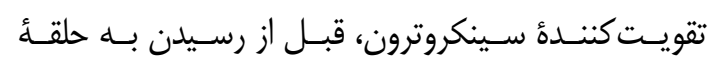

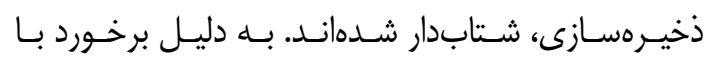
مولكولهاى كازى و رويدادهاى ديكر، جريان حلقه بلهطور

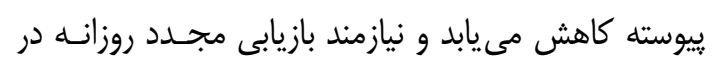

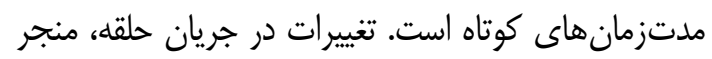

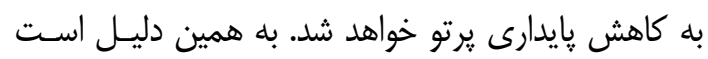

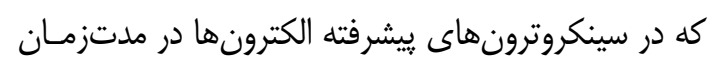
كوتاه به حلقه تحويل داده مىشوند [8].

ع. معرفى بخشى از تكنيكهاى ثرتوايكس توليدشده در سينكروترون

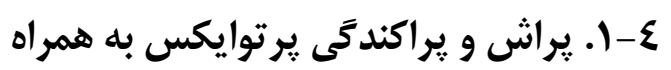
تكنيكهاى مرتبط

يراش، زمانى رخ مى دهد كه يكى موج الكترومغناطيسى بـا

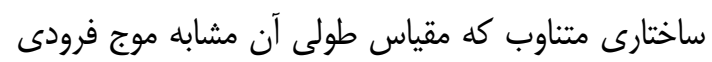

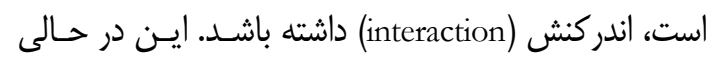

ميدان مغناطيسى (B) از آهنربا بستخى دارد: $P \propto E^{2} B^{2} y I$

طول مسير الكترون است كه در طى آن تابش، به نـاظر

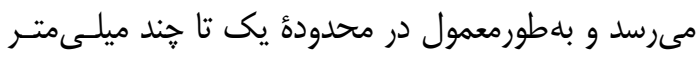
است. I جريان حلقهُ ذخيرهسازى است. به شرطى كه ده ناظر

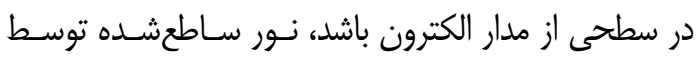
يك الكترون در قوس دايرهاى بلهصورت خطى قطبى شده آندا

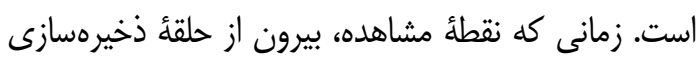

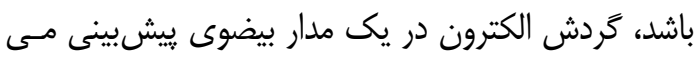

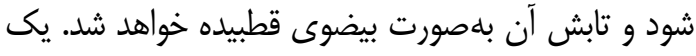

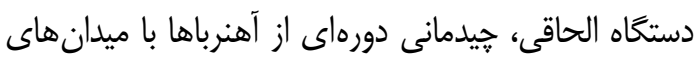
مخالف يكديخر است كه با طولموج نوسان

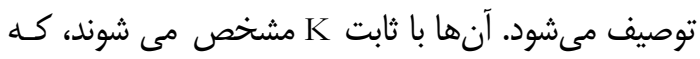

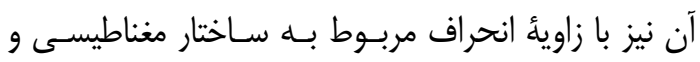

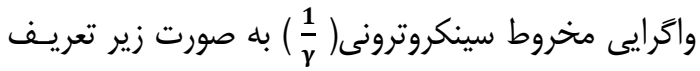

$$
\mathrm{K}=\frac{e B \lambda_{u}}{2 \pi m_{e} c}
$$

دستخاههاى الحاقى، بلعنوان مغناطيس لرزانتـده (K> 10)

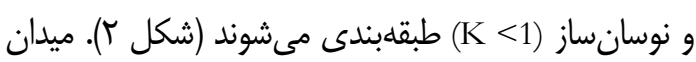
مغناطيسى نوسان سازها، باعث انحراف ضـعيفى در مس مسـير

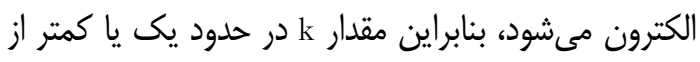

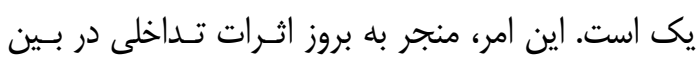

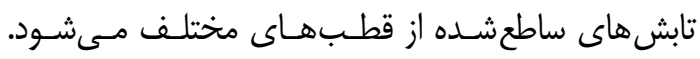

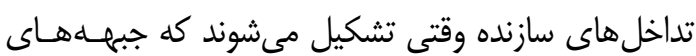

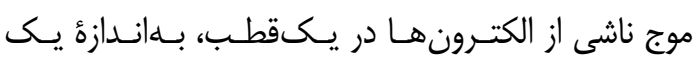

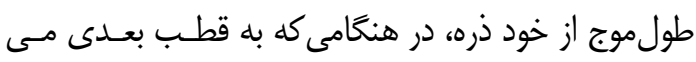

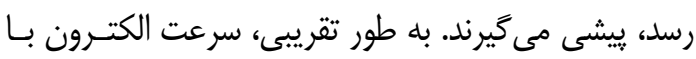

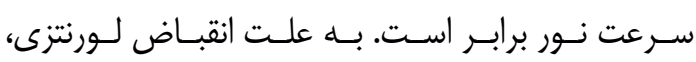

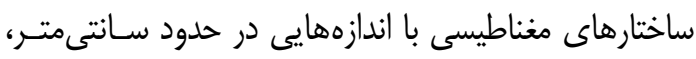

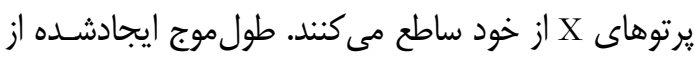

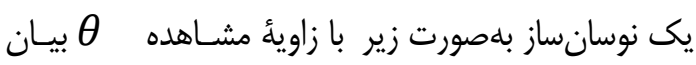

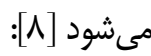

$$
\lambda_{f}(\theta) \approx \frac{\lambda_{u}}{2 \gamma^{2}}\left(1+\frac{K^{2}}{2}+(\gamma \theta)^{2}\right)
$$

توزيع طيفى در حول طولموج بنيادى و هماهنــهـا، بـا

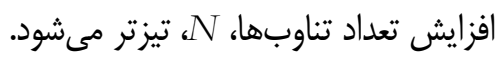

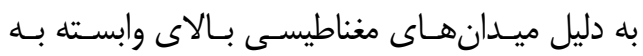

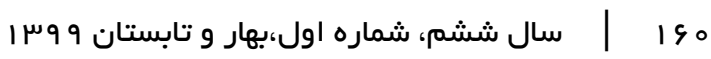




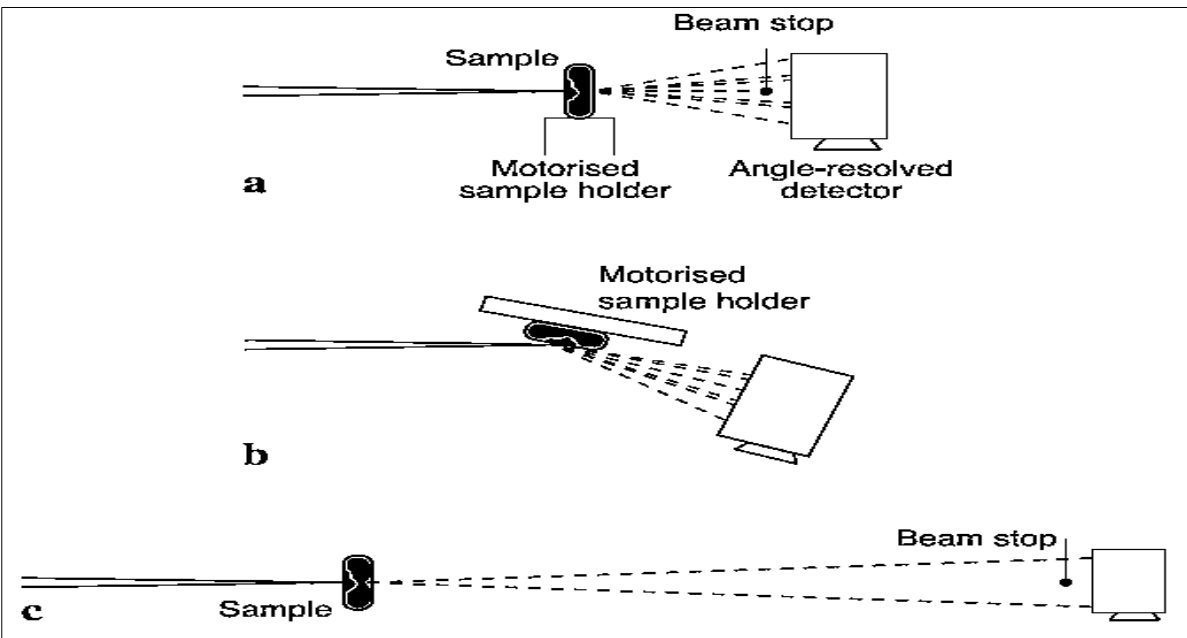

شكل ": طرحوارهى نمايش الفXXRD در هندسه عبورى ب) در هندسهى انعكاسى ج 8RD

Fig. 3: Pattern of a(XRD in the transmission geometry, b) XRD in the reflection geometry, and c) SAXS [8]

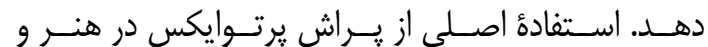

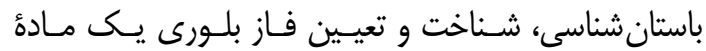

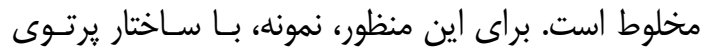

ايكس عبورى و انعكاسى بررسى مى مَود [9].

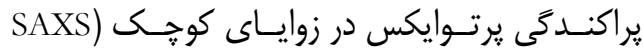
[Small angle X-ray scattering]

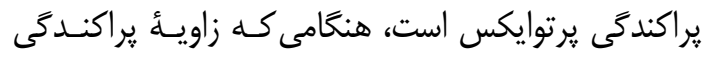

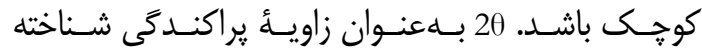

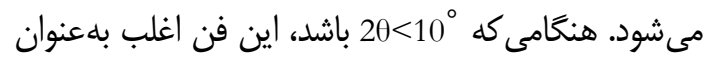

SAXS
است كه يراكندگى يرتوايكس شامل توصيف كلى فرآينـد

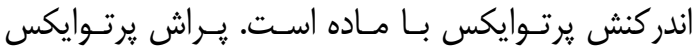

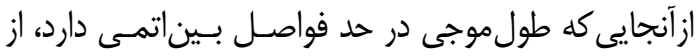

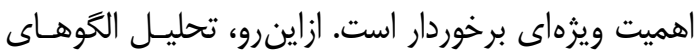
يراش يرتو x اطلاعات مفيدى را در مورد ساختار مولكولى يرحي

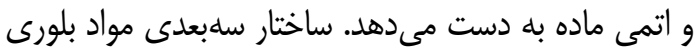

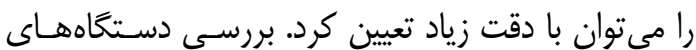
بـىشكل، مانند شيشه و مايعات، به دليـل فقـــان سـاختار

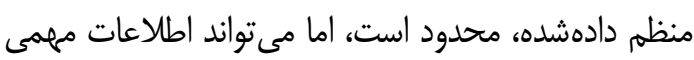
را از قبيل متوسط فواصل بينمولكولى يا بــيناتمسى ارائسه

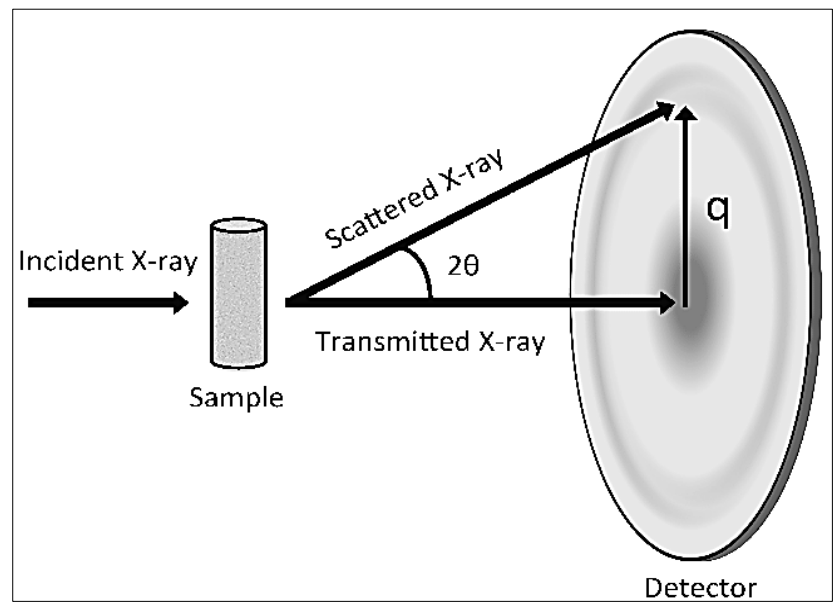

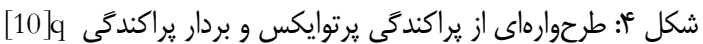

Fig. 4: Schematic of $\mathrm{x}$-rays scattering and scattering vector q [10] 
استفاده از اين فن، مى توان آنـاليز عنصـرى را بـهـــــورت

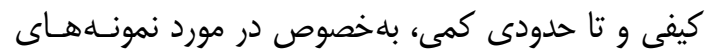

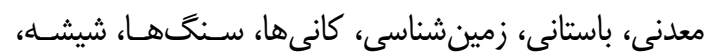

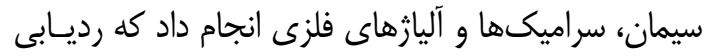

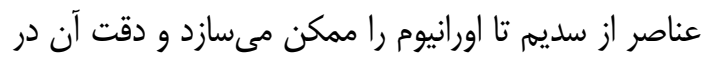
رديابى عناصـر ســـَين، بيشـتر اسـت. در سـينكروترون،

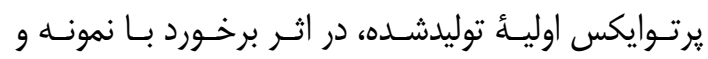

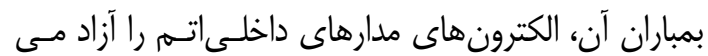

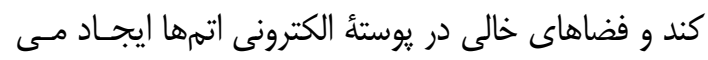

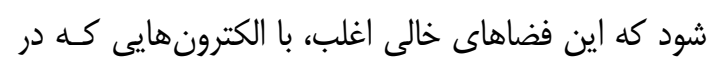

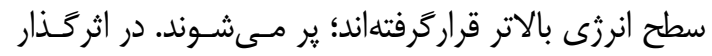

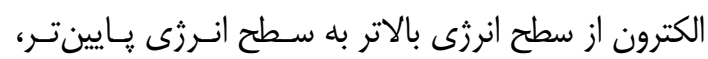

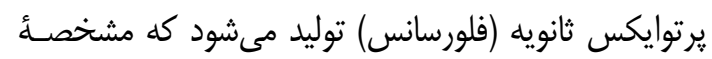

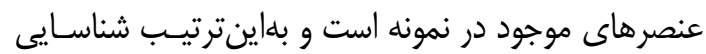

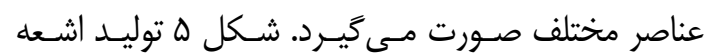

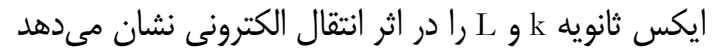

\section{ع-" ط. طيفسنجى جذب ثرتوايكس (XAS)}

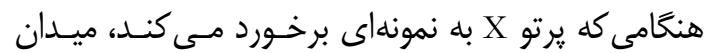

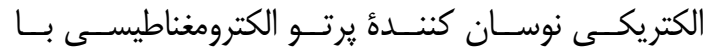

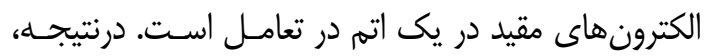

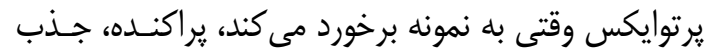

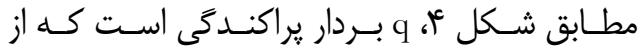

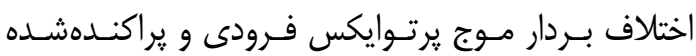
حاصل مىشود. رابطؤ بين فضاى حقيقى و فضـاى وارون

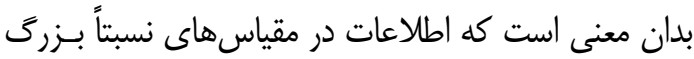

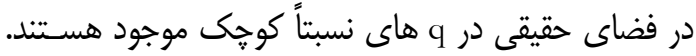

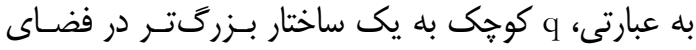
حقيقى مربوط است [10].

ع-r. طيفنغارى فلورسانس ير توايكس طيفنغارى فلورسـانس يرتـوايكس، از روشهـاى آنـاليز

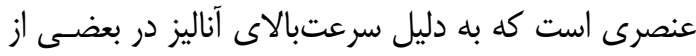
صنايع، اهميت زيادى دارد. اين فن، توانـايى انجـام آنـاليز عنصرى را بلهـورت كيفى و نيمـهـ كمّى در نمونسهـهـا، بهخصوص نمونههاى معلنى، دارد. در اثر تابش يرتوايكس

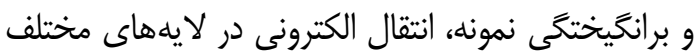

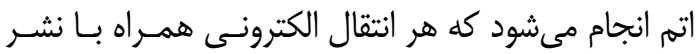

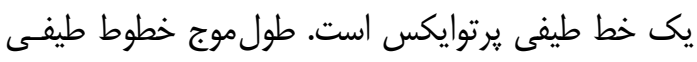

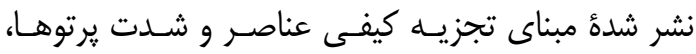

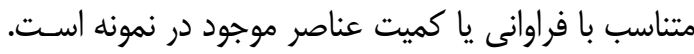

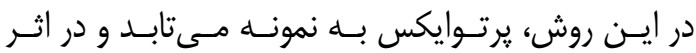

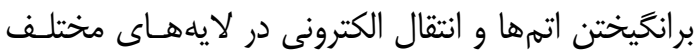

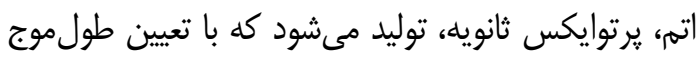
(انرزى) يرتوايكس ثانويه كه مشخصأ اتم است، مىتـوان

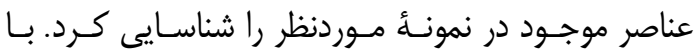

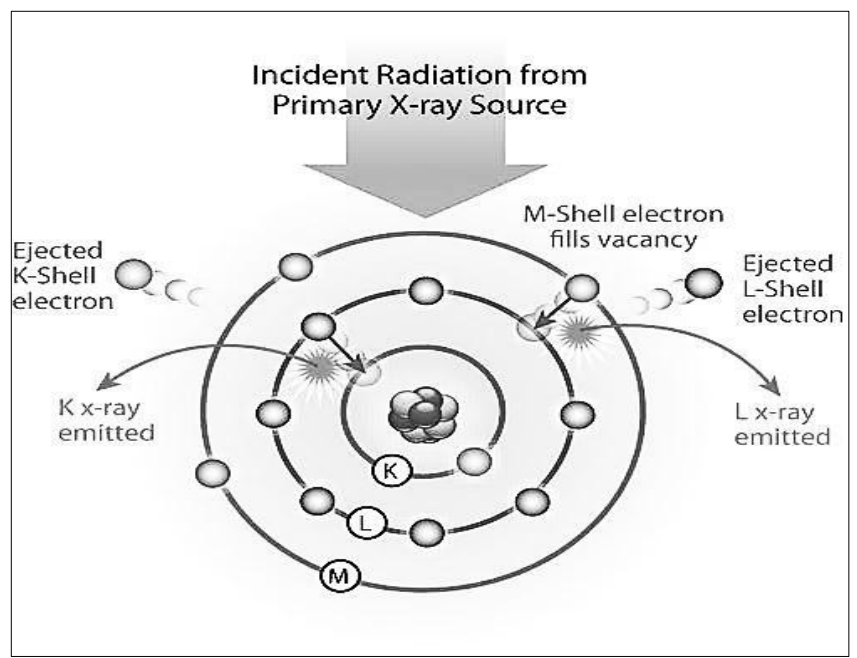

[12]XRF شكل ه: طرحوارهاى از

Fig. 5: Schematic of XRF [12] 


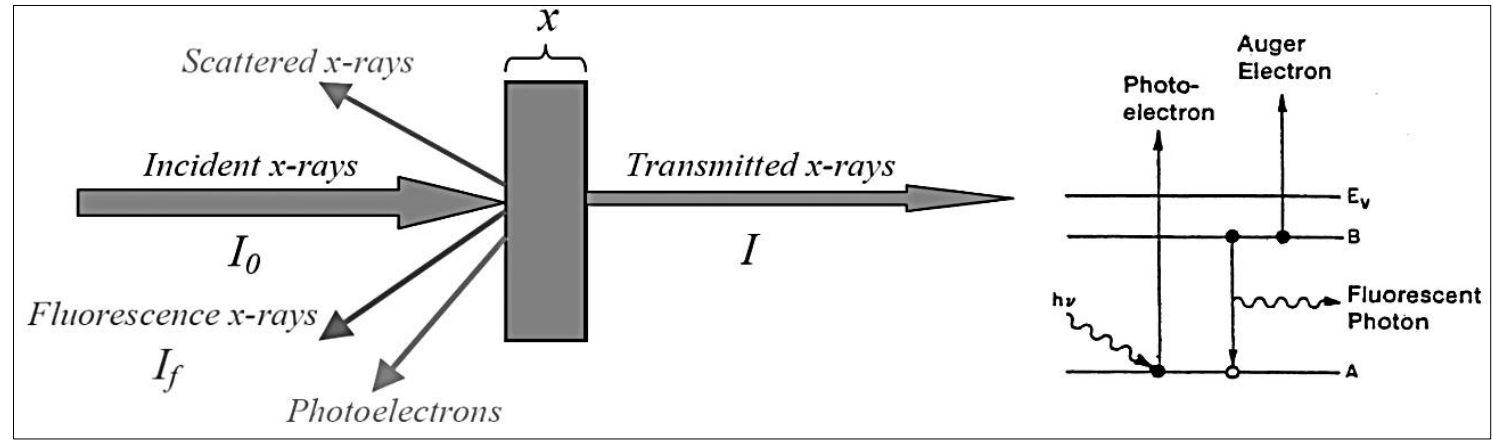

شكل و: طرحوارهاى از اندركنش يرتوايكس با يك نمونه

Fig. 6: Interaction of $\mathrm{x}$-rays with a sample

ناحيأ نزديك لبه (XANES) كه انرزى يرتوايكس فرودى E= $\boldsymbol{E}_{0} \pm \mathbf{1 0 e v}$

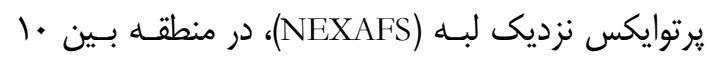

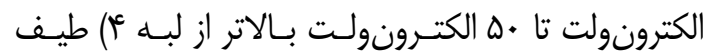

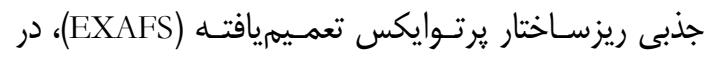

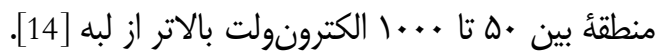

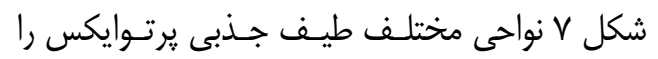

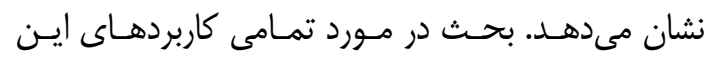

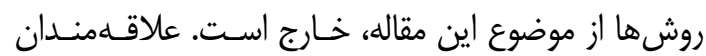
براى مطالعأ بيشتر به مرجع [15] مراجعل فرمايند.

\section{ع-ع. توموكرافى رايانهاى يرتوايكس}

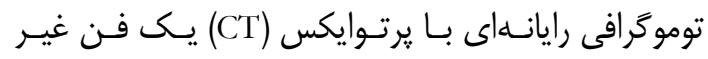

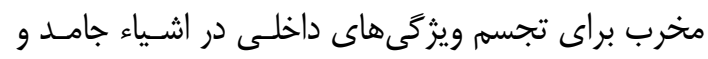

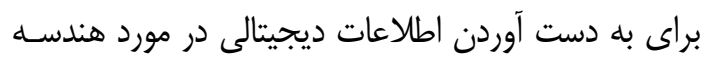

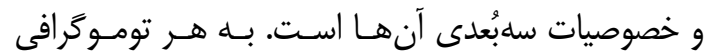

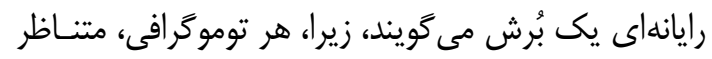
با لايهنغارى جسم موردنظر اسـت. تصـوير ديجيتـالى، از يك سرى بيكسل (عناصر تصـوير) تشـكيلشـــــ اسـت،

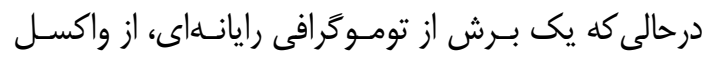

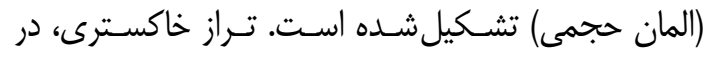

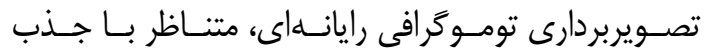

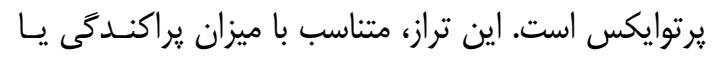

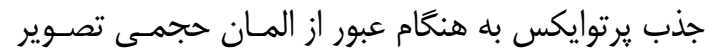

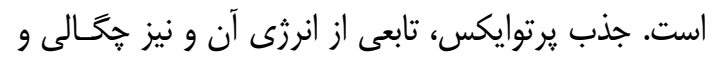

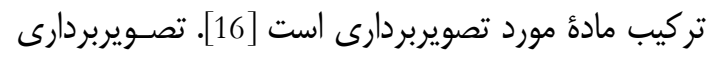

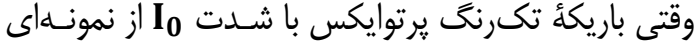

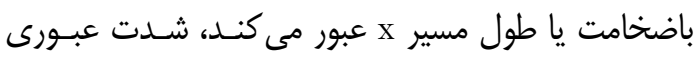

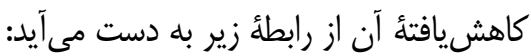

$$
\ln \left(\frac{I_{0}}{I}\right)=\mu x
$$

كه

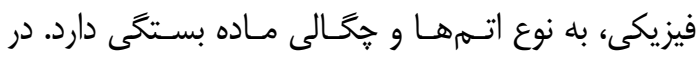

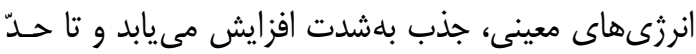

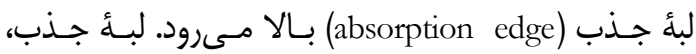
انرزى اى است كه در آن، يك افزايش تنـد و غيرمنتظـره،

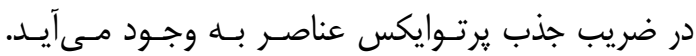

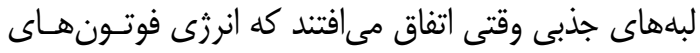

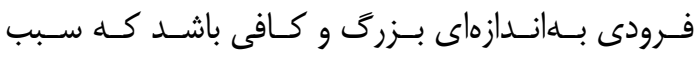

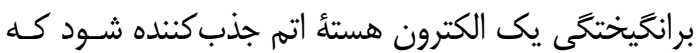
درنتيجه يك فوتوالكترون توليد مىشود؛ بنـابراين انسرزى هـ

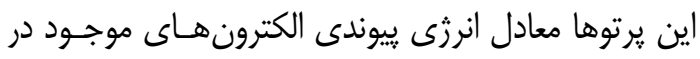
لايههاى K،L،M و...اتم جذب كننده است. لبههاى جـذب، برحسب انرزى برانغيختن يك الكترون از لايئ داخلى بــهـ لايههاى ديخر بهصورت، مى شوند [13]. هر عنصرى، انرزى لبهُ جذب

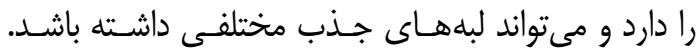
بنابراين از لبههاى جذب، در شناسايى ساختارى مسى دئسوان

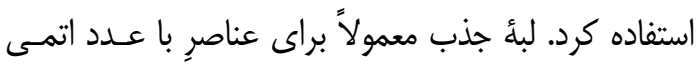

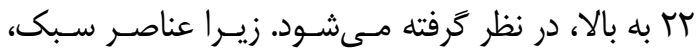

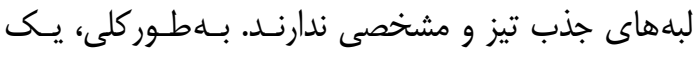

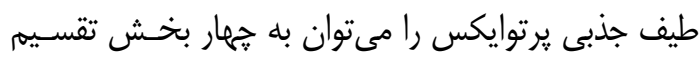
كرد: () ناحئ ييش لبه (F)

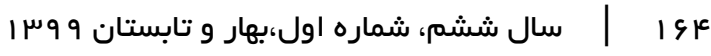




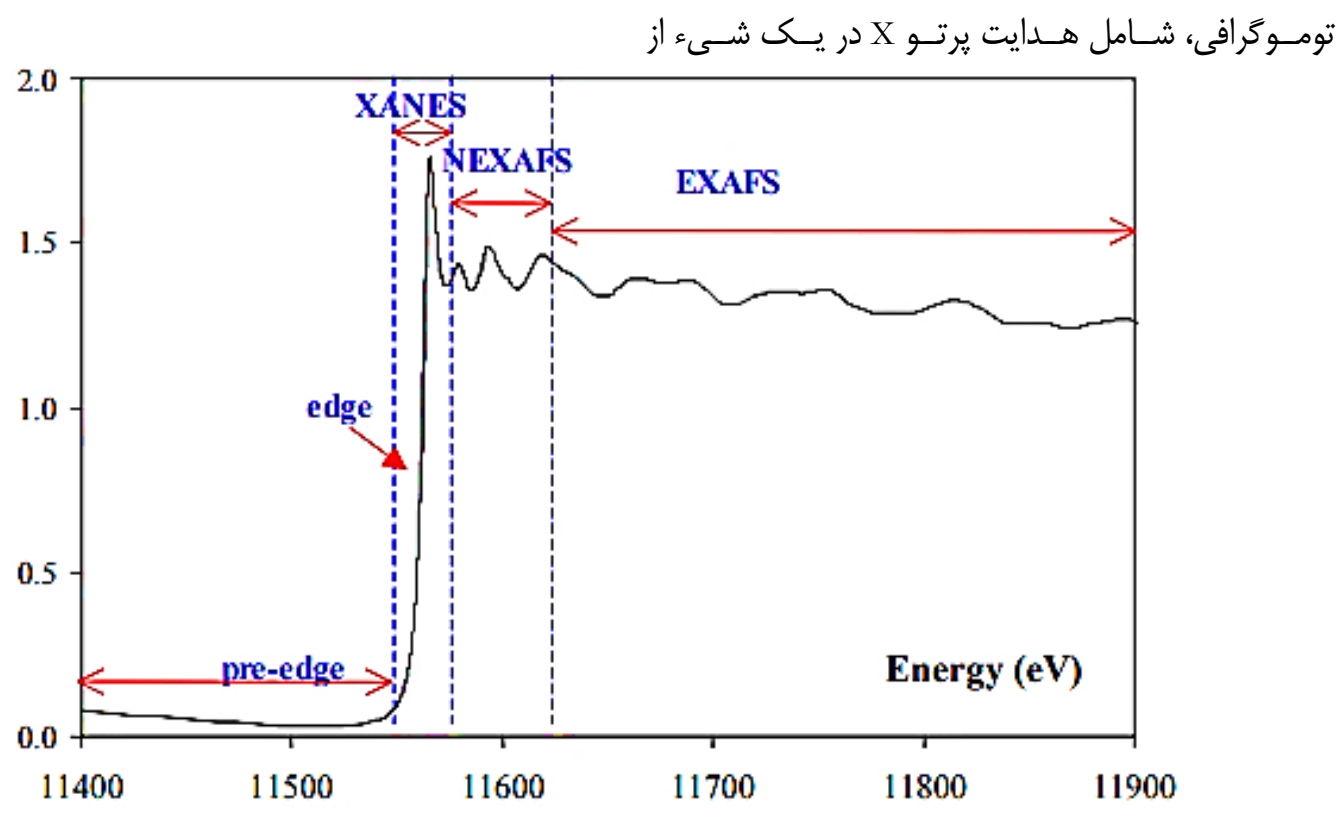

شكل V: نواحى مختلف طيف جذبى يرتوايكس [14]

Fig. 7: Different regions of x-ray absorption spectrum [14]

بيشينه و كمينه دارند كه مىتوانند براى اهداف مقايسـاهى

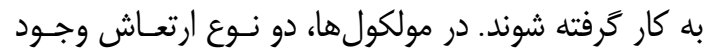
دارد كه در اصطلاح، ارتعاشهاى كششى و خمشى ناميده

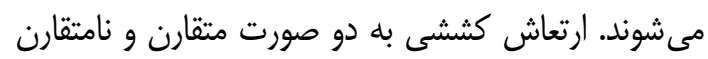

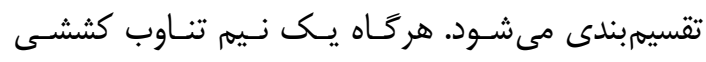

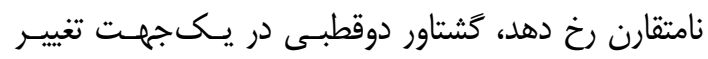

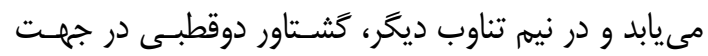

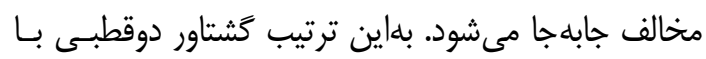

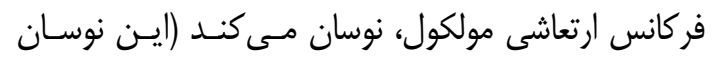

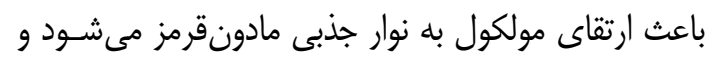

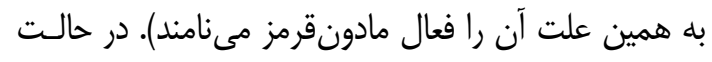

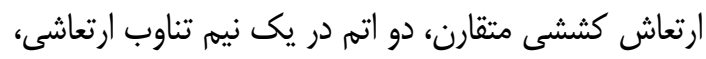
در جهات مختلف حركت مى كنند كه در اين صورت تغيير

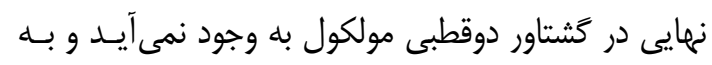

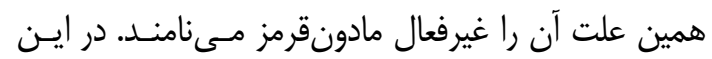

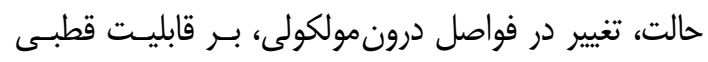

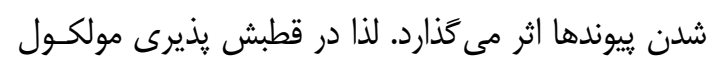

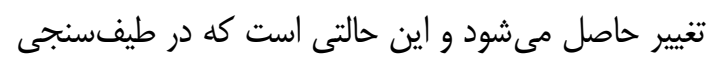

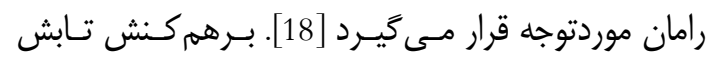

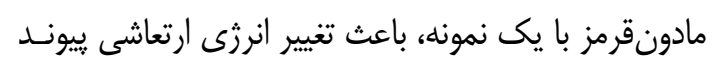

جهتهاى متعدد و اندازمخيرى كاهش شدت در طول يك سرى از مسيرهاى خطى است. اين كاهش توسـط قـانون

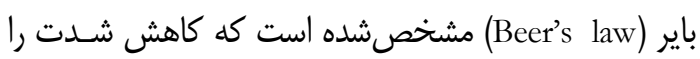

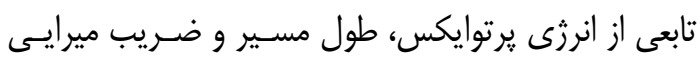

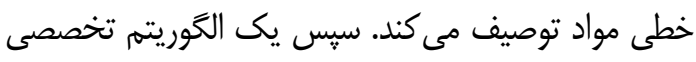

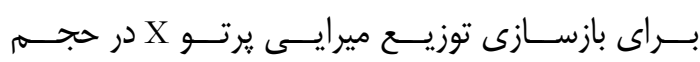
تصويربردارى مورداستفاده قرار مى يَيرد [17].

\section{ع-0. روش طيفسنجى تبديل فورية مادونقرمز مبتنى بر سينكروترون}

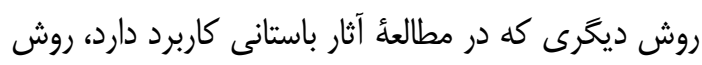

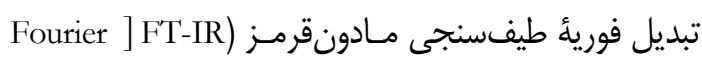
طف [Transform Infrared

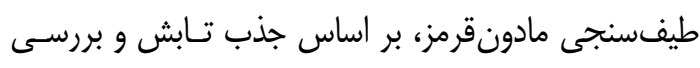

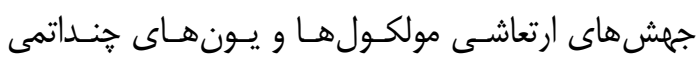

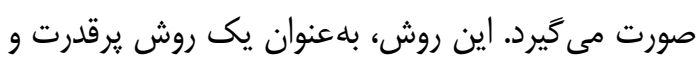

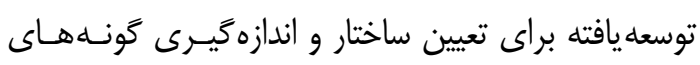

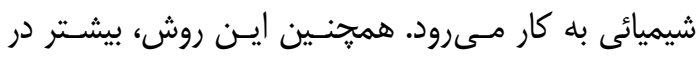

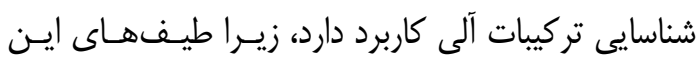

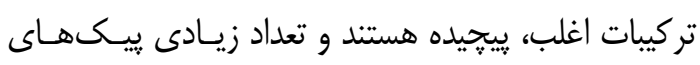


زيادى از لوازمآرايشى مورداستفاده در مصر باستان كـه در

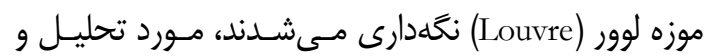

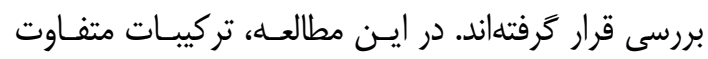

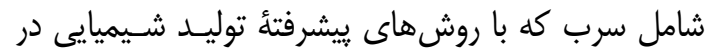

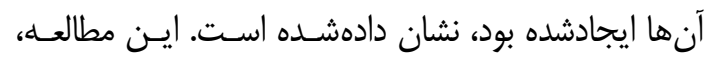

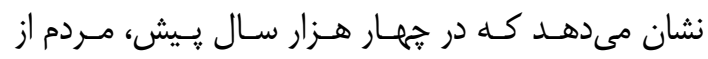

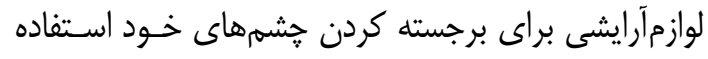

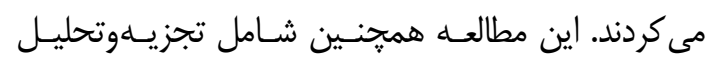

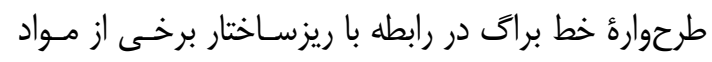

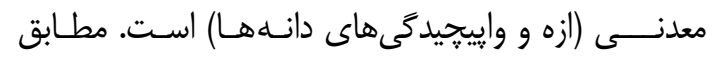

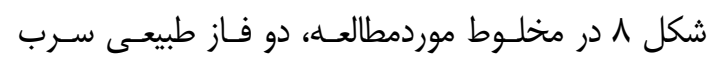

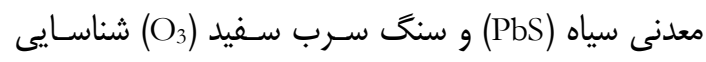

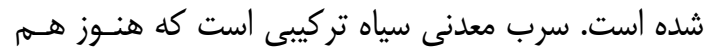

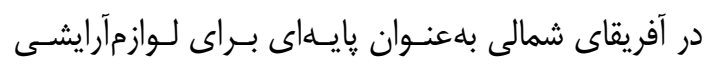

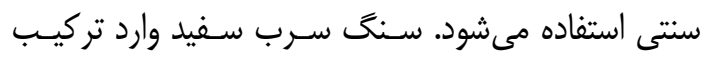

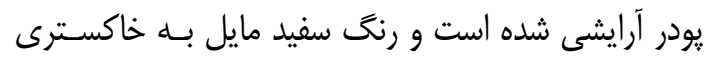

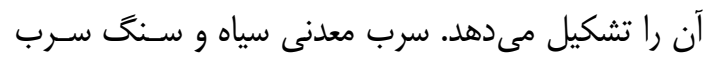

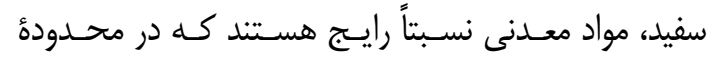

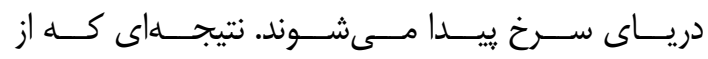

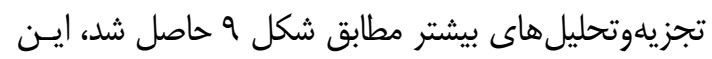

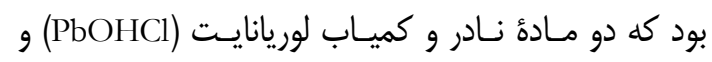

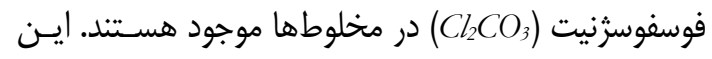

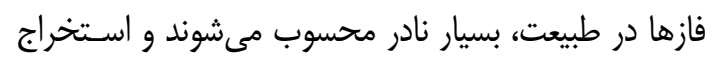

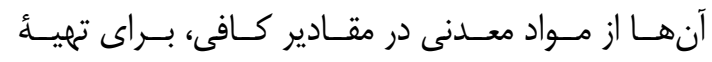

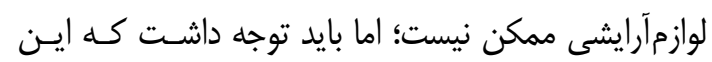

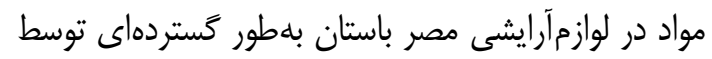

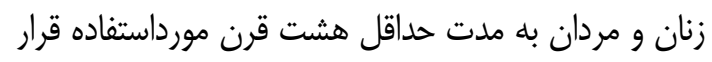

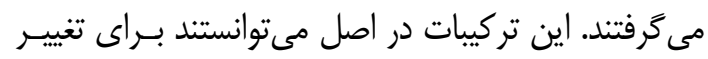

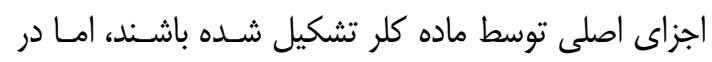

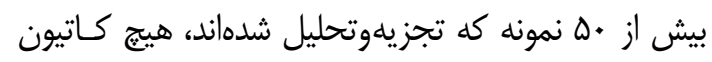

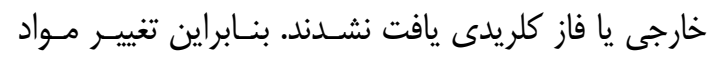

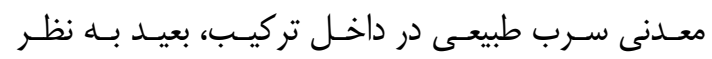

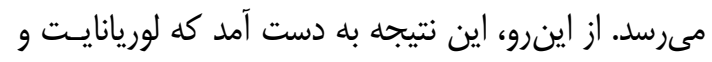

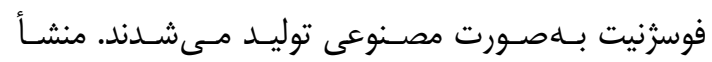
ســاختخى بـــودن PbOHCl

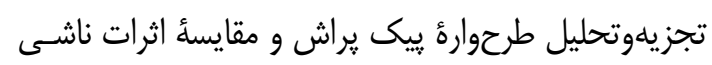

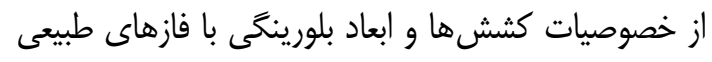

در مولكولهـاى آن مــشـود كـهـ روش مناسـبى بـراى

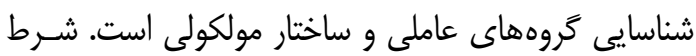

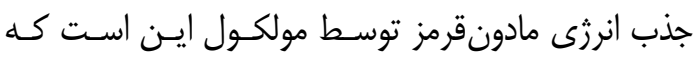

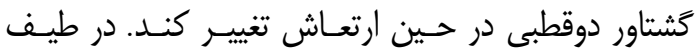

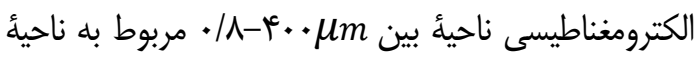
مادونقرمز است ولى ناحيهاى كه جهت تجزيــأ شـيميائى

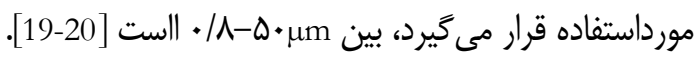

\section{ه. مثالهايى از كاربرد تكنيكهاى معرفىشده

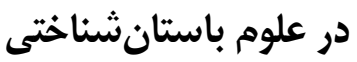 \\ ه- ا. كاربردهاى مبتنى بر سينكروترون با استفاده

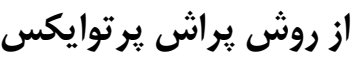

يكى از كاربردهاى مهم سينكروترون در باستانشناسى، استفاده از روش يراش يرتوايكس است. اسـتفاده از ايـن فئن

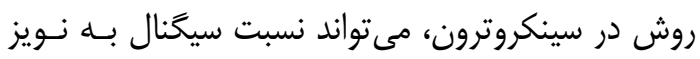

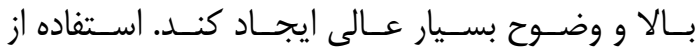

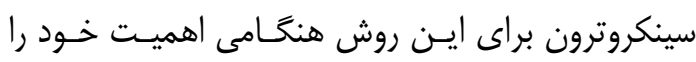

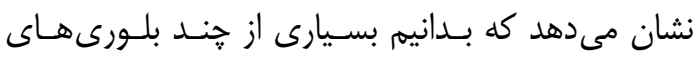

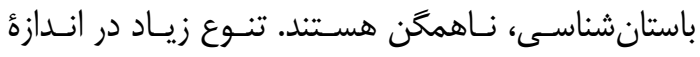

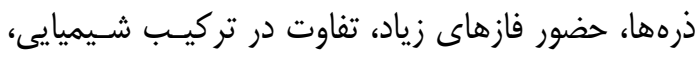

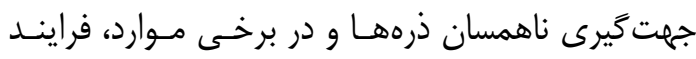

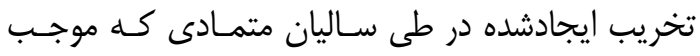

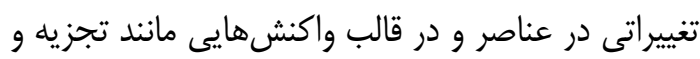

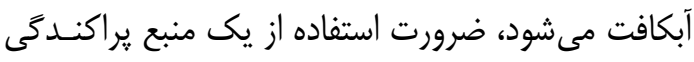

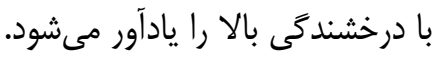
ويثگى خـاص تـابش سـينكروترون (قابليـت تنظيميم

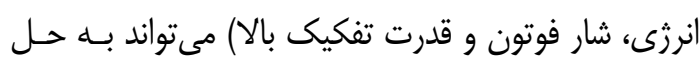

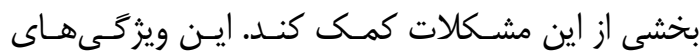

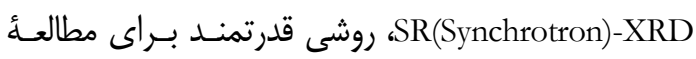

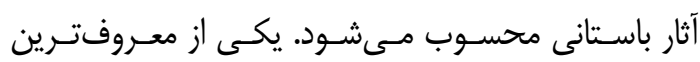

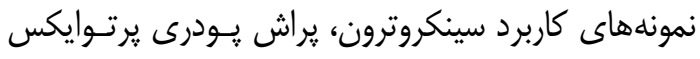

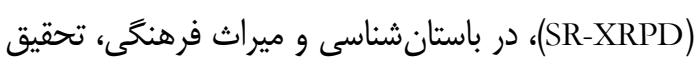

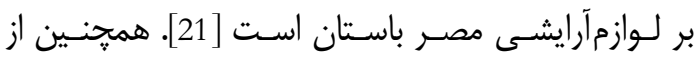


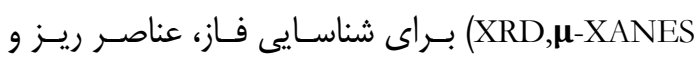

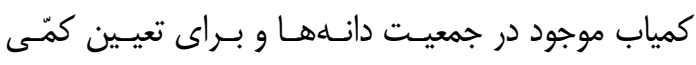
مراحل مختلف تشكيل لوازمآرايشى استفاده مى جـود. تعداد 


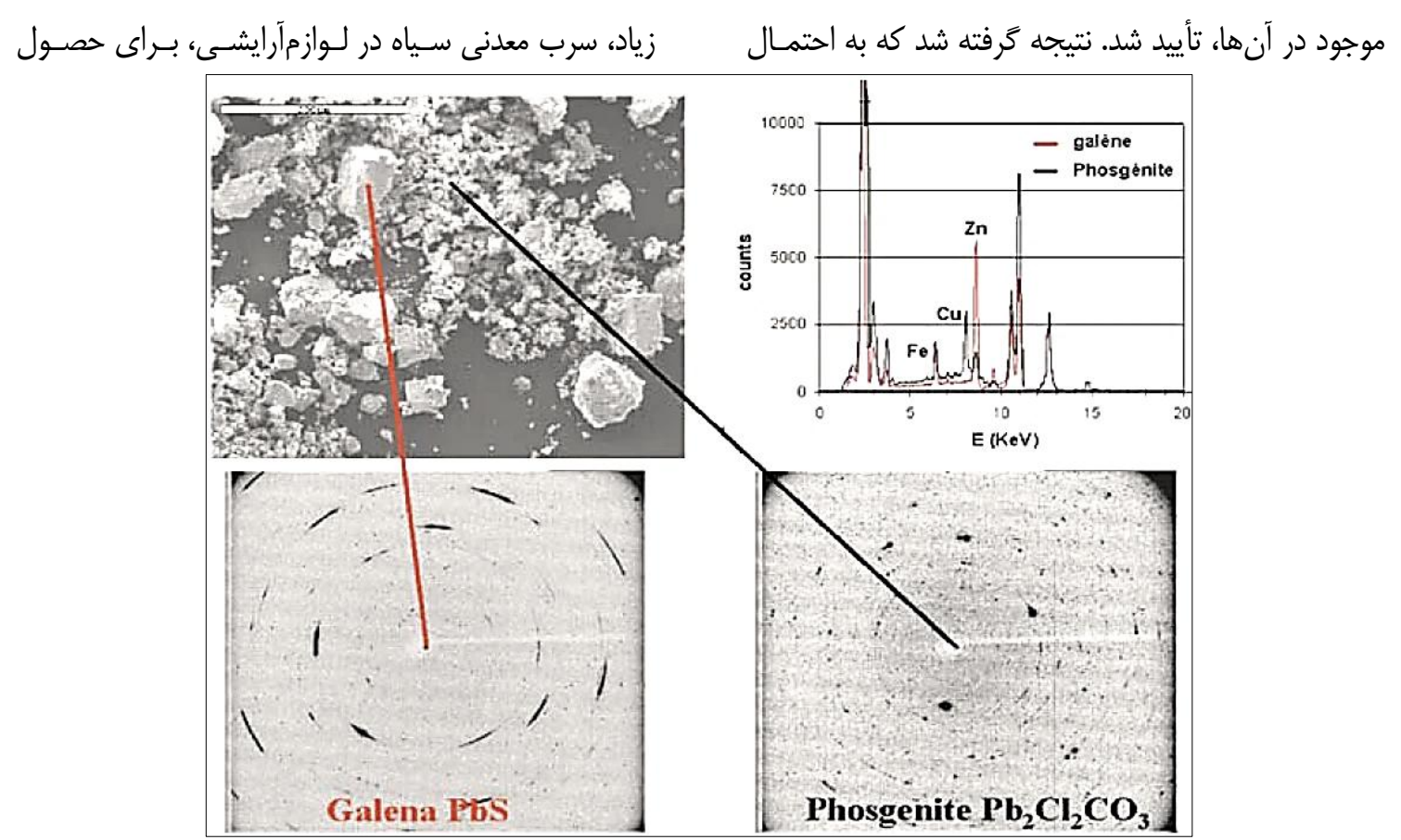

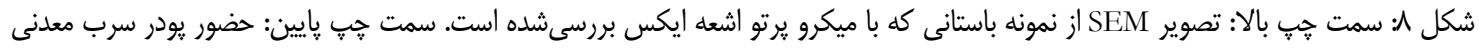

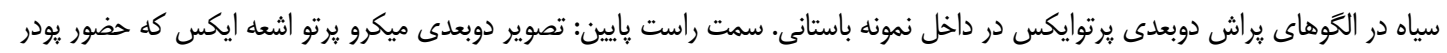

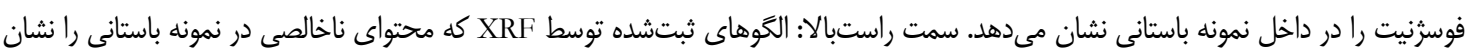
مى دهد [23].

Fig. 8: up-left: SEM image of a sample investigated by x-rays. Down-left: presence of the black mineral lead powder in 2D xray pattern. Down-right: 2D image of micro $x$-ray in the presence of phosgenite in the sample. Up-right: XRF pattern that shows the impurity content in the sample [23].

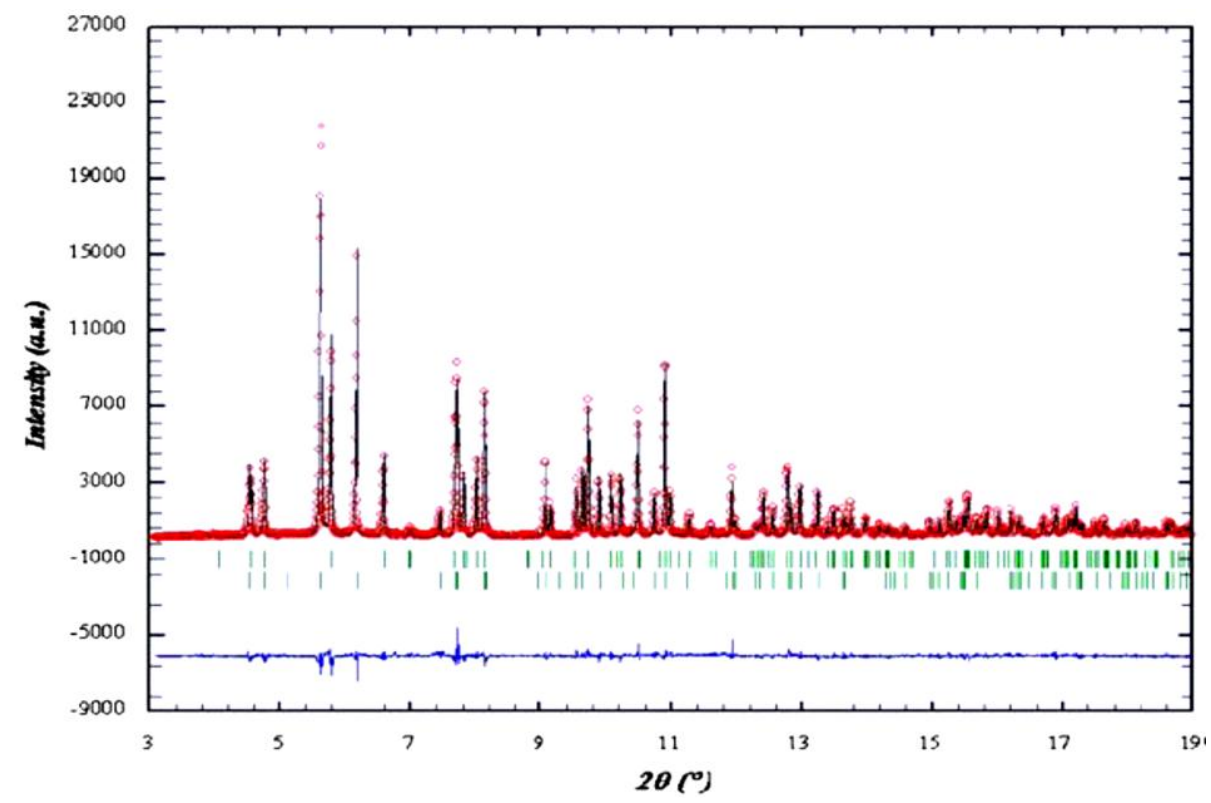

شكل 9: طرحواره يراش مشاهدهده (نقطهها) و محاسبهشده (خطوط) براى لوريانايت، فوسثنيت و سنگ سرب سفيد. نشانگرها، موقعيت خطوط

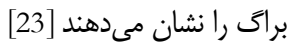

Fig. 9: X-ray scattering pattern (dots) and calculated (solid line) of phosegenite and while lead stone. The pointers show the Bragg peak positions. 


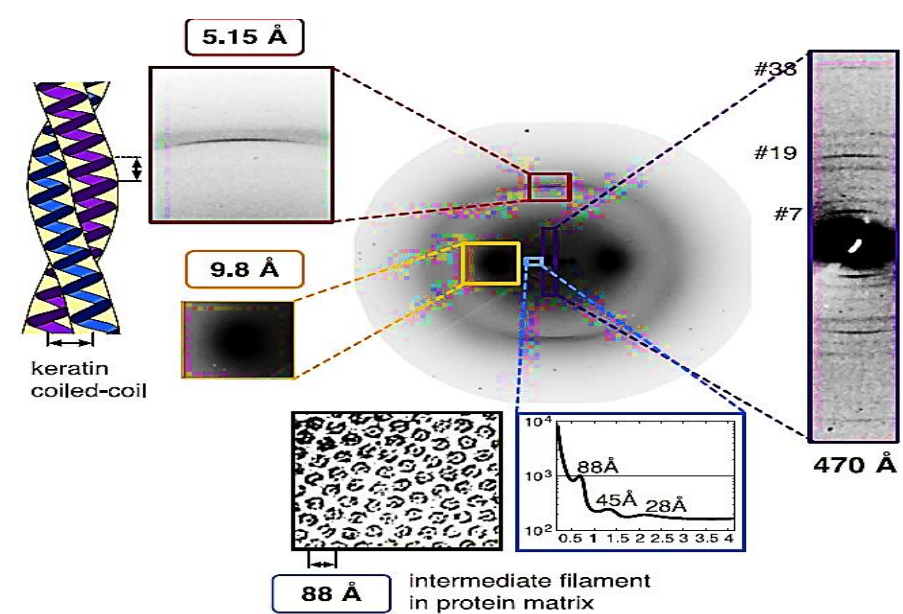

شكل • ا: تصوير SAXS از موى يك موميايى مصر باستان، ابر مولكولهاى موجود در كراتين -آلفا باقابليت وضوح آنكستروم از ماكرو مولكولهاى موجود در آن تشخيص يذير هستند [26].

Fig. 10: SAXS image of a hair from a mummy form ancient Egypt, super molecules in Chratine-alpha are distinguishable from macromolecules with a resolution of about Angstrom.

مؤلفههاى يروتئينى نسبت داد [27-26].

\section{ه-r. كاربرد طيفسنجى تبديل فورئُ مادون قرمز مبتنى بر سينكروترون در باستانشناسى}

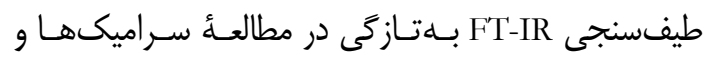

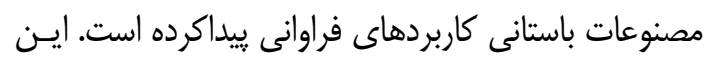

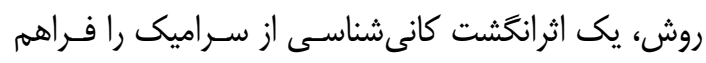

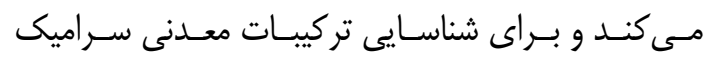

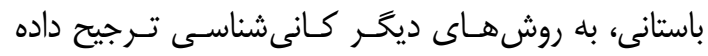

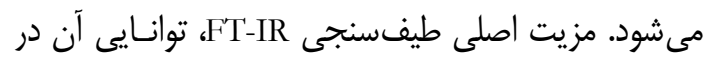

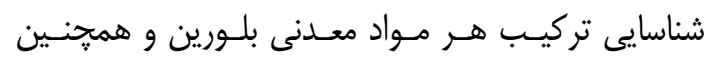

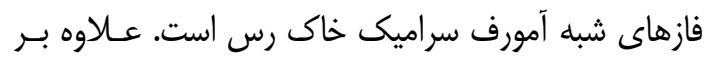

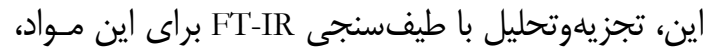
تا حدودى، غير مخرب است، زيرا فقط مقدار كمى از مـواد

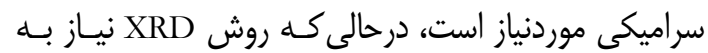

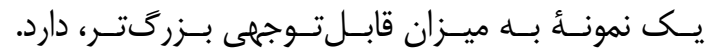

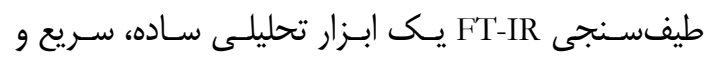

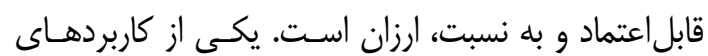
طيفسنجى FT-IR معرفى عناصر يك جسم است. روش يك بُعد كمّى را براى تجزيهوتحليل كانىشناسى عنى
بافت و اثرات آرايشى مطلوب، بـه صـورت يـودر در آمـده است. برعكس، طرحواره ييكى لوريانايت و فوسرنيت، فاقـد

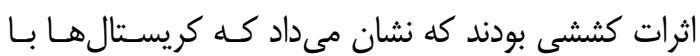
سنتز مستقيم توليد مىشوند. حال سؤال ايـن اســ: هـرا تركيبات سفيد براى اضافه كردن به سـرب معـدنى سـياه

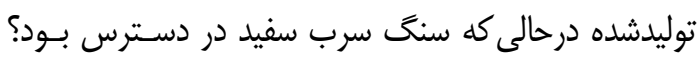

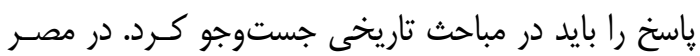

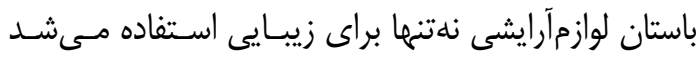
بلكه براى خواص درمانى نيـز كـاربرد داشـتند. در متـون سحر و جادوى گريكو-رومان اشاره مى شود كـه رسـوبات

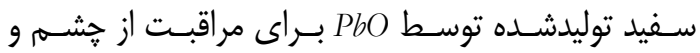
يوست مناسب است. اين تركيبات سرب مىتواند بلعندـان

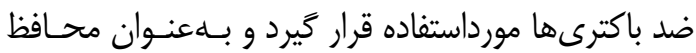
جشم در برابر اشعهُ نور خورشيد استفاده شود [22-25].

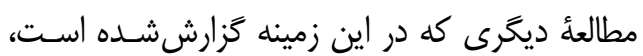

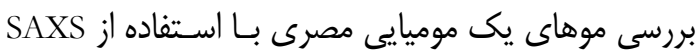
است. درواقع اين مطالعه نشان داد كه ساختار ابر مولكولي

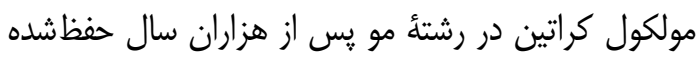
است. با استفاده از روش بهينه سازى تضـاد (contrast) در

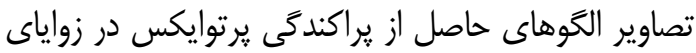

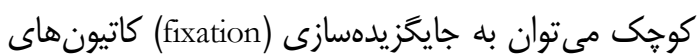

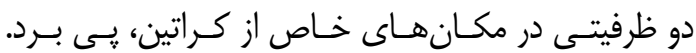

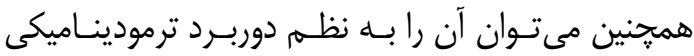



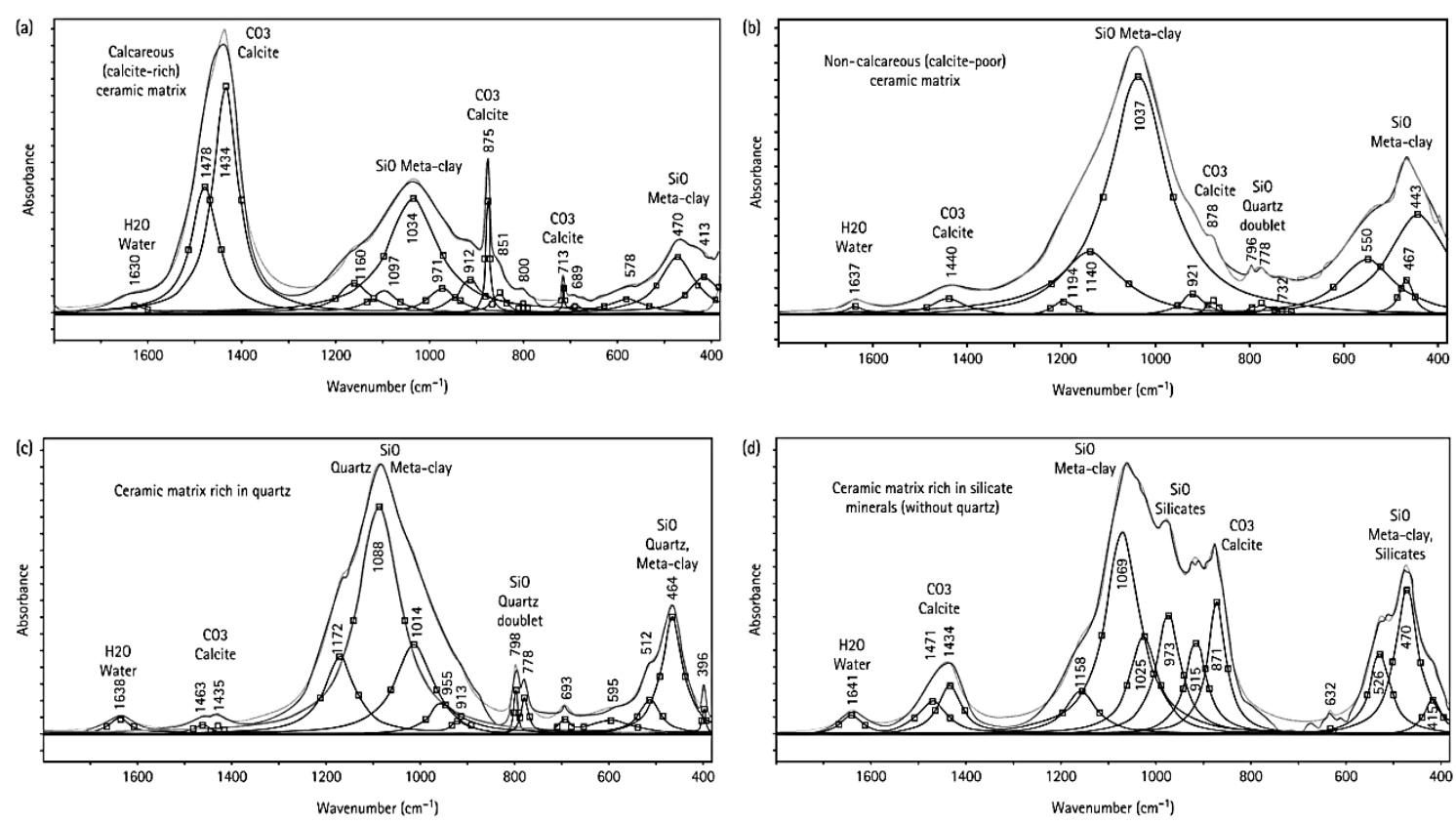

شكل ||: دادهاى برازش شده طيفهاى FT-IR مواد سراميكى از سفال هاى سراميك سر آههاى لوانتين [28] Fig. 11: Fit to FTIR data from cermic material of Levantine sight

وارداتى و الكَوى احتمالى مبادلات تجارى يـا مبادلـه بـين موقعيت و مناطق مجاور و درنتيجه زمينأ اجتمـاعى توليـد سفال را نشان مى دهد [29].

\section{7. كاربرد تكنيكهاى مبتنى بر سينكروترون در شناخت مكانيسم تخريب آثار باستانى}

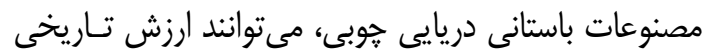

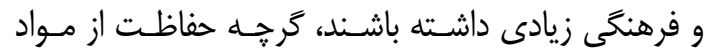

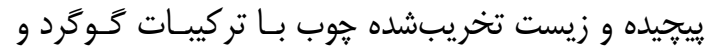

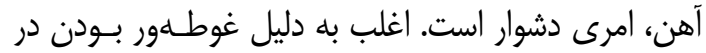
رسوبات اعماق دريا شرايط حفظ اين مواد فراهم مىشـود، همان طور كه براى كشتى جنَّى سـوئدى واسـا (Vasa)

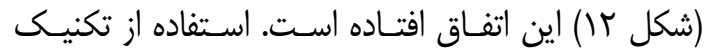

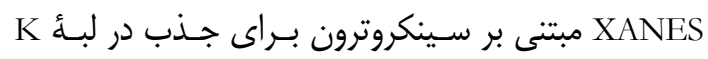

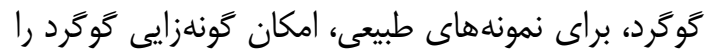

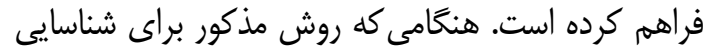

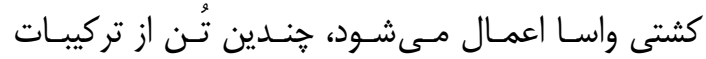

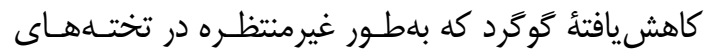

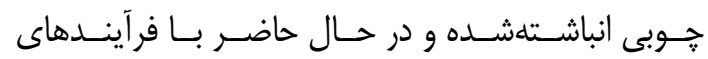

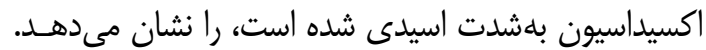

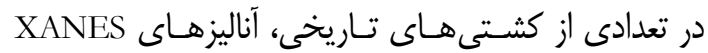

سر اميكهاى باستانى اضـافه مـى كنــــ شـــت نسـبى يـا

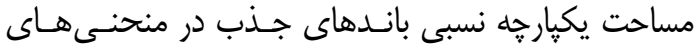

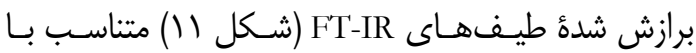
غلظت مواد موجود در نمونــه هـا اسـت و بنـابراين مقــــار سنجى مواد معـدنى شناسـايىشـده را ممكـن مسىسـازد.

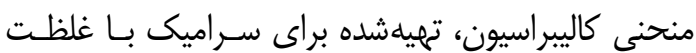

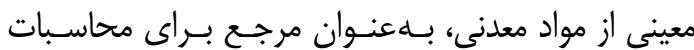
استفاده مىشود [28]. همجنين از تحليل طيفسنجى FT-IR براى ارزيـابى

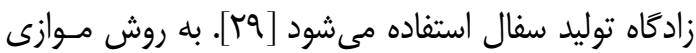

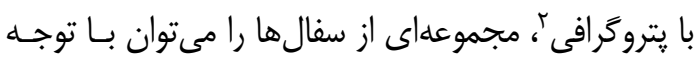

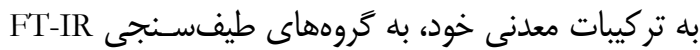

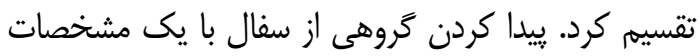

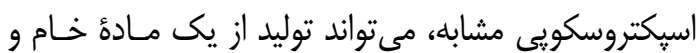
به همين ترتيب، توليد در يك مكان واحد را نشان دهد. از

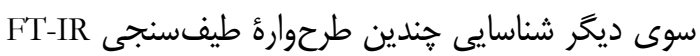

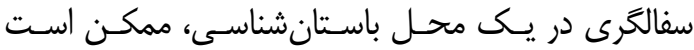

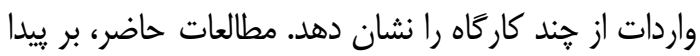

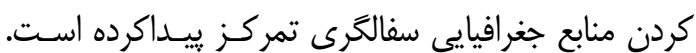

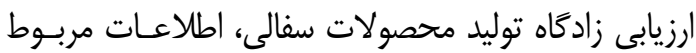

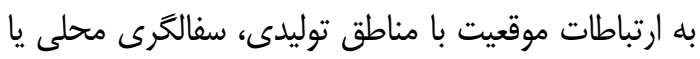

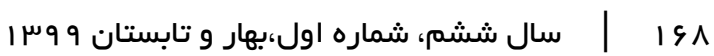




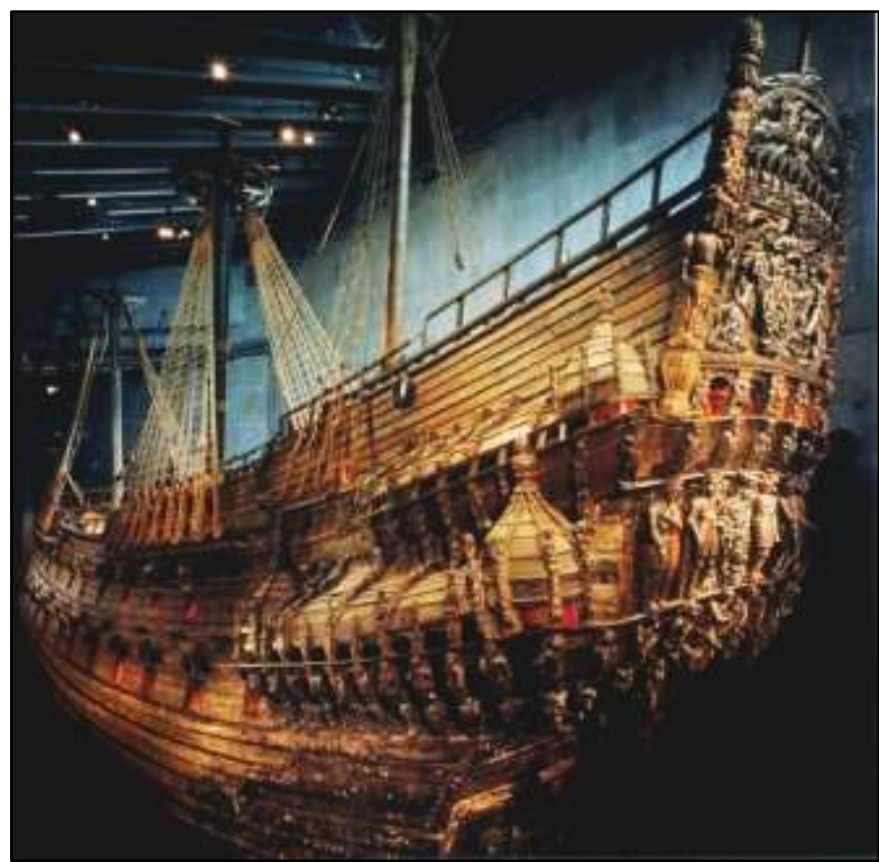

شكل r) إ: واسا پֶ از محافظتهاى لازم در نمايشكاه موزه واسا [30]

Fig. 12: Vasa wreck after needed treatments in Vasa exehbition [30]

يرتوايكس ذرات (PIXE) براى قسمتى از نمونـهـ بــهــور

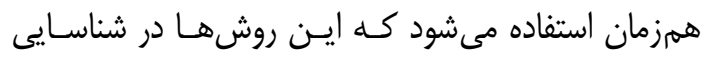

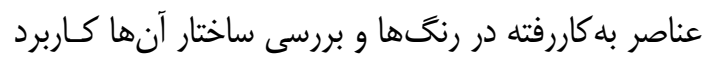

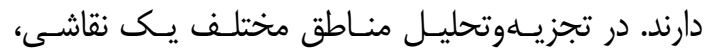

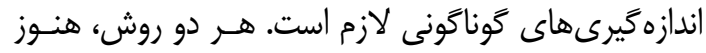

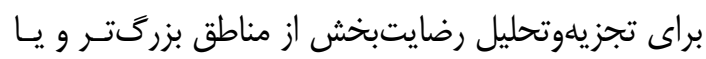

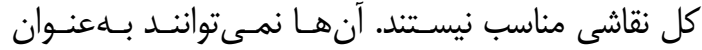

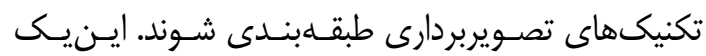
مشكل جدى است، زيرا خواص شـيميايى منـاطق مجـاور

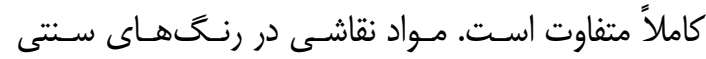

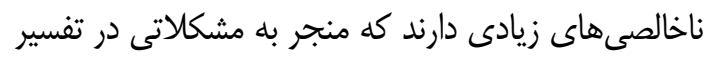

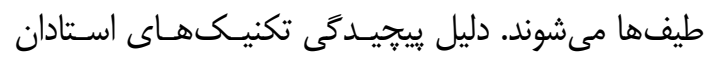

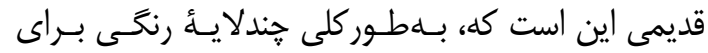

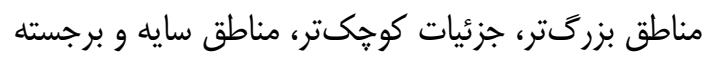

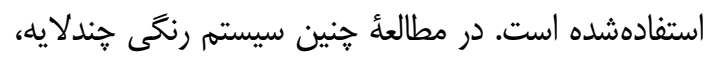

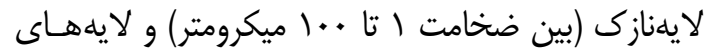

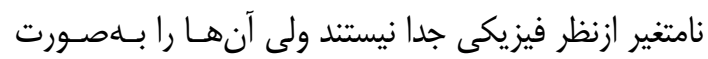

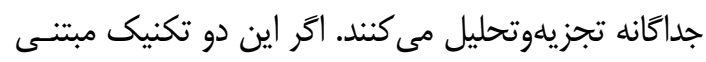
بر سينكروترون انجام شود، همأ اين مشكلات حل خواهد شد و اين موضوع، قدرت سينكروترون و تفاوت آن را با
تر كيبشده با XRF نشان مىدهد كه تركيبـات كـوَرد و

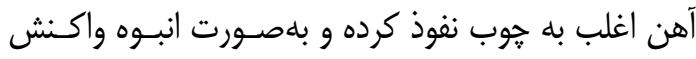

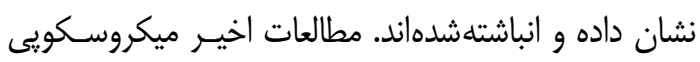
اشععُ ايكس نشان مىدهد كه سولفيد هيدروثن توليدشــــ

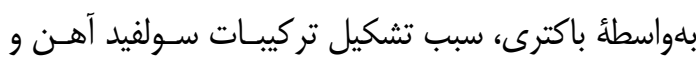

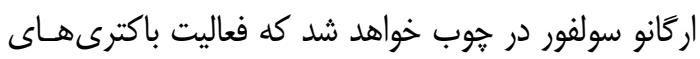

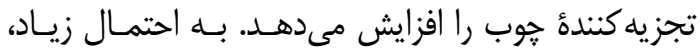
اكسيداسيون سولفيدهاى آهن، علت اصلى اسـيدى شــن إند

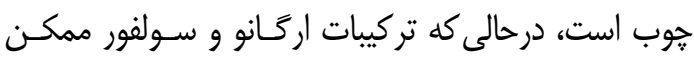

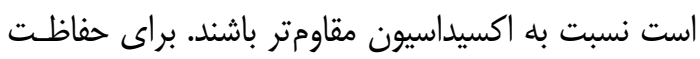

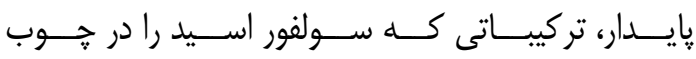
تشكيل مى دهند، بايد در صورت امكان، همراه با اسـتخراج

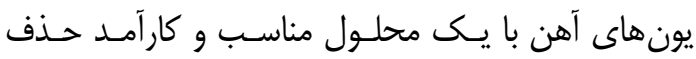

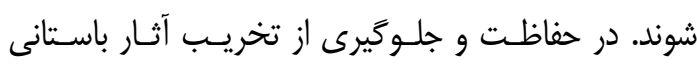
دريايى، يكى از اين روشها مىتواند مؤثر واقع شود [30].

\section{V. نمونهاى از برترى سينكروترون نسبت به

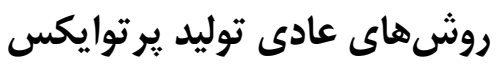

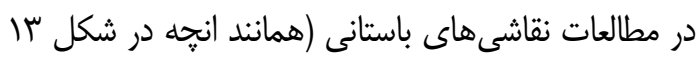

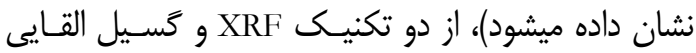




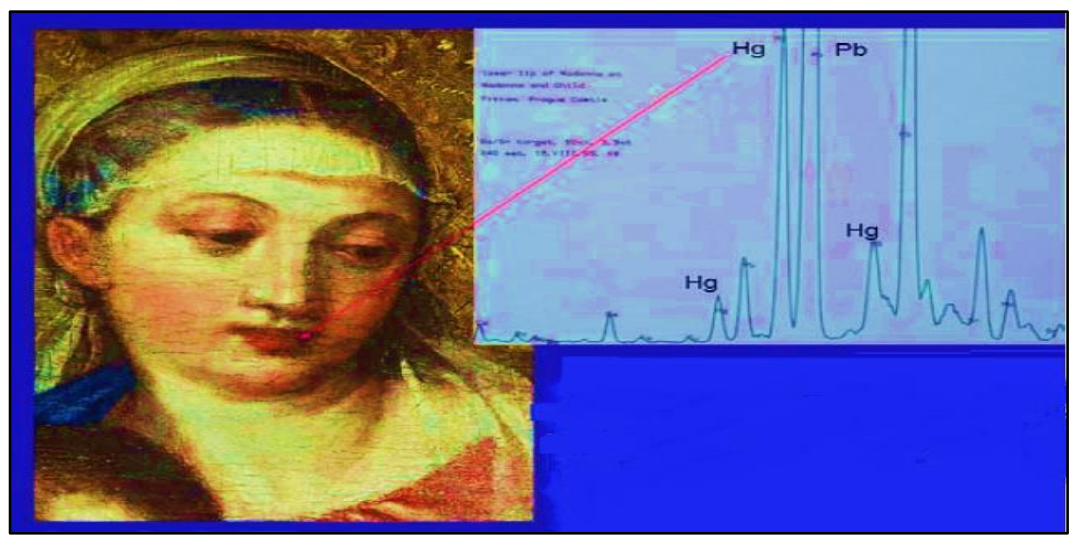

شكل سا: Hg حضور رنخ قرمز روشن را نشان مىدهد درحالى كه Pb به دليل حضور سرب سفيد است [32] Fig. 13: Hg shows the bright red, while Pb shows while lead [32]

ساختار و روش ساخت مهره را نشان داده است. برجستخى بخش مركزى، از يك قطعه :جوب، بـهـهـاى ايجـاد آن از

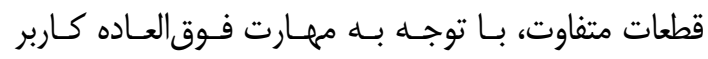
دستىساز آن ايجادشده است. علاوه بـر ايـن، قطعـهاى از

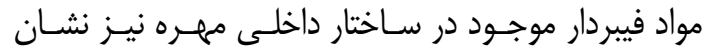

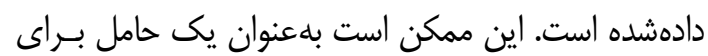

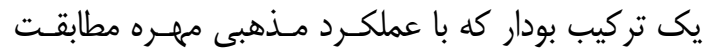
دارد، بهار فتته است [35-34].

\section{9. جديدترين يزوهشها در ايران و جهان} يكى از جديدترين يزوهشها در ايران، مطالعه بر تكههاى

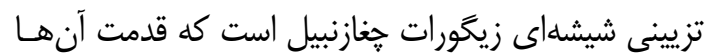

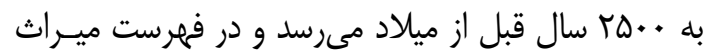

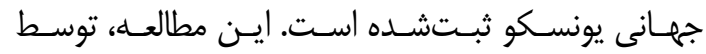

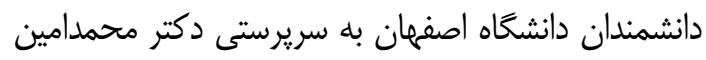

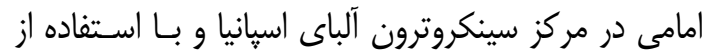

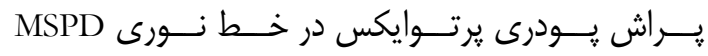

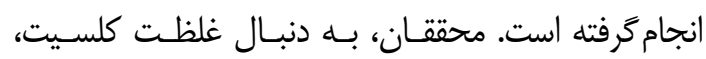

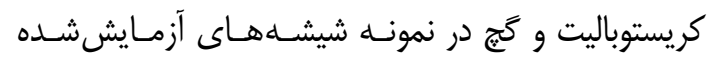

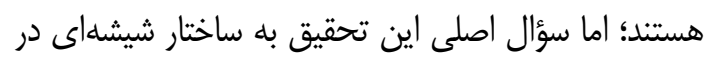

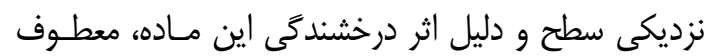

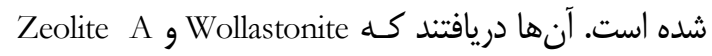

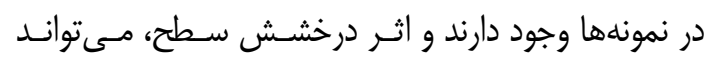
ناشى از حضور اين مواد باشد[36]. يثروشش بعدى كه در سال •r.r. م. منتشرشده است،

$$
\text { منابع ديخر نشان مىدهد [32-31]. }
$$

\section{^. سينكروترون و نقش آن در احيا، بازسازى و توليد آثار مشابه با اشياء باستانى}

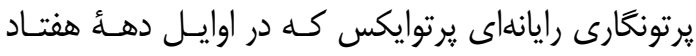

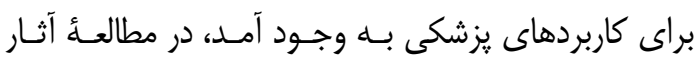

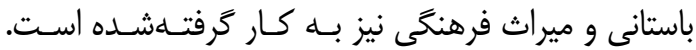

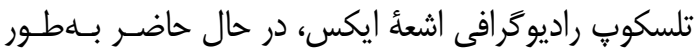

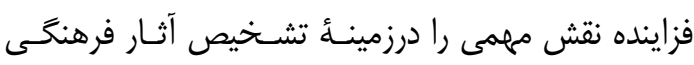

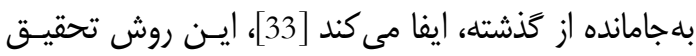
غير مخرب قدرتمند، قادر به نمـايش سـابعـدى حجـهم و ساختار داخلى اشياء است. اطلاعات بهدست آمده، در تعيين روشهاى حفاظت و بازسازى اين آثار بسـيار مهـم اسـت.

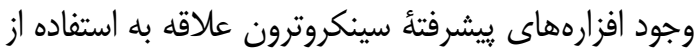
اين فن را در ميان باستان شناسان افزايش داده است. يكى ئن

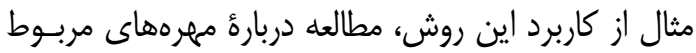

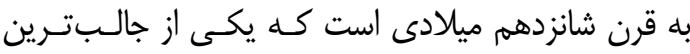

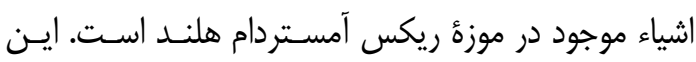

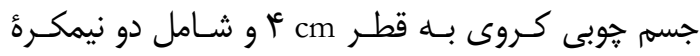

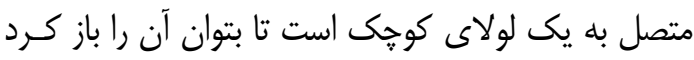

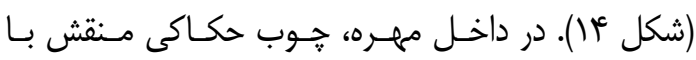
صحنههاى زندگى مسيح است. اين مينيـاتورىهـا سـطح

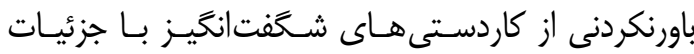

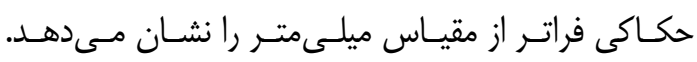

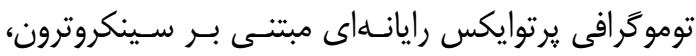

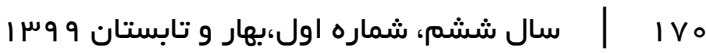




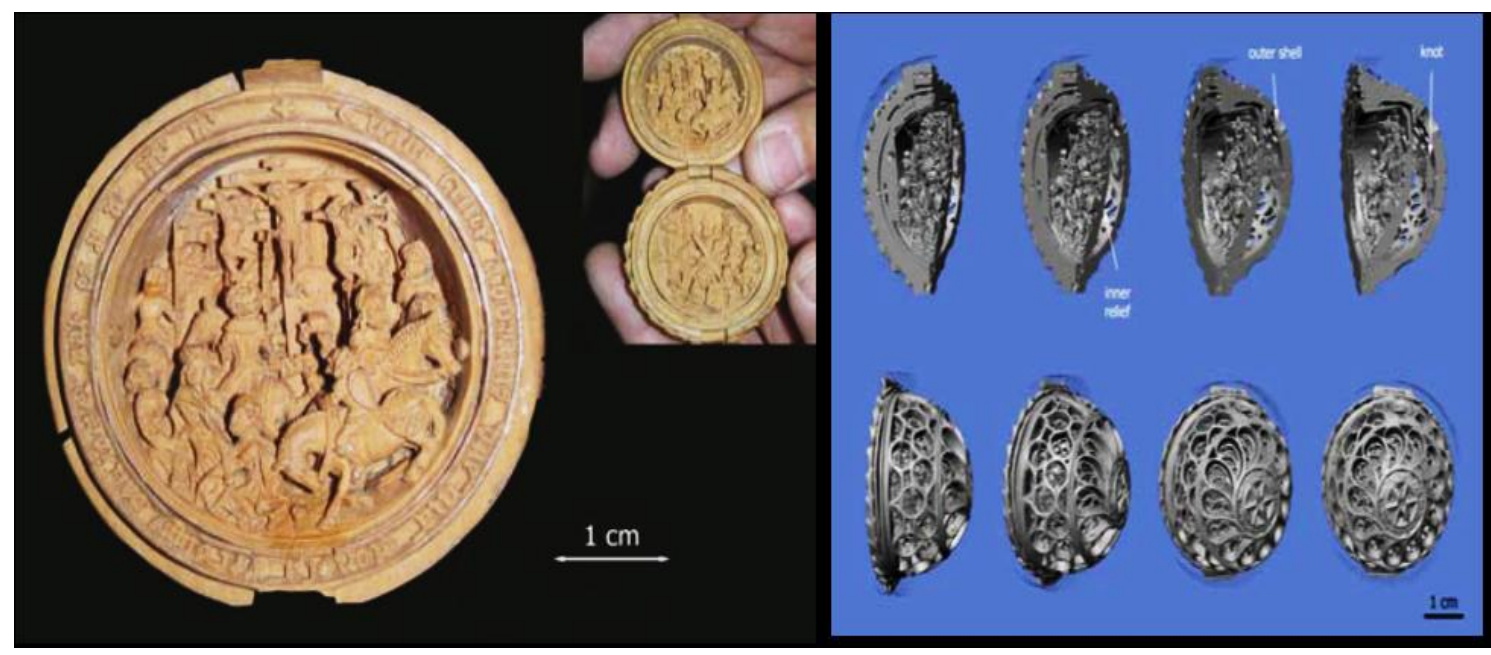

شكل fا: سمت هِ: مهرهاى كه طرح مسيح به صليب كشيده شده را نشان مىدهل. سمت راست، رديف بالا: بازسازى حجمى با برش عمودى از

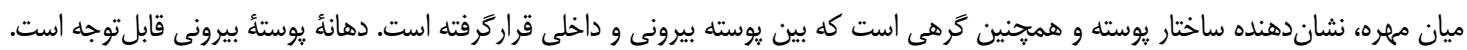

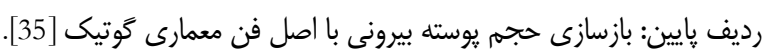

Fig. 14: Left - Boxwood prayer nut with Christ carrying the cross and the crucifixion, c. 1515, Rijksmuseu Amsterdam, The Netherlands. Right - Upper row: volume reconstructions with a vertical cut through the middle of the nut, revealing the shell structure as well as the knot sandwiched between the outer and inner shells. Note the openings in the outer shell. Lower row: volume reconstruction of the outer shell with Gothic motif.

حوزهاى مختلف بيشازييش احساس مى شـود. بـاءيـن

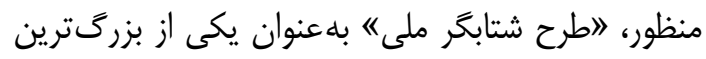

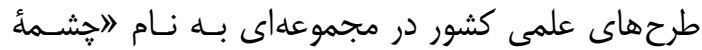

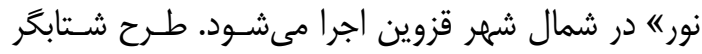

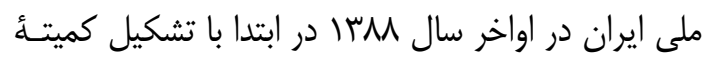

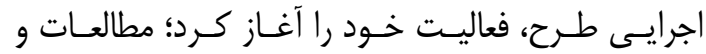

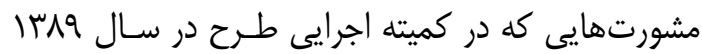
انجام شد، نشان داد كه به دليل تحقيقات متنوعى كه در

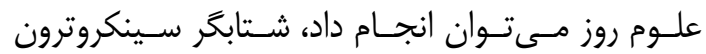

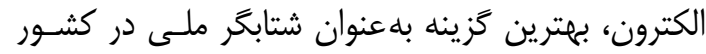

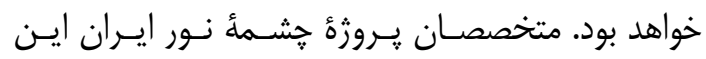

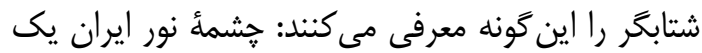

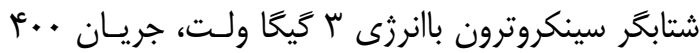

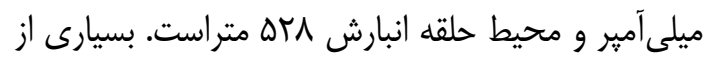
محققان ايرانى مرتبط با تحقيقات سـينكروترون كـه در

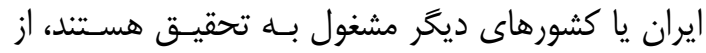

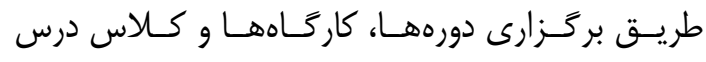
كروههاى آموزشى، شناسيى شدهاند و اطلاعـات مربـورط

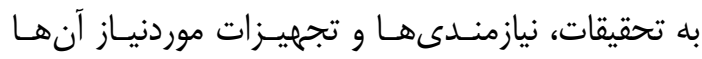

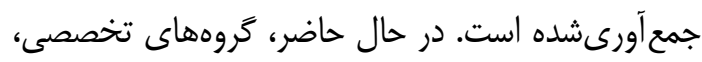

از محصولات لعاب سياه در خط نورى PUMA (مركز سينكروترون سوليل فرانسه) است. مطالعات باستانسنجى

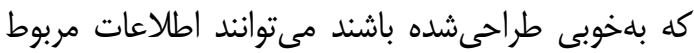

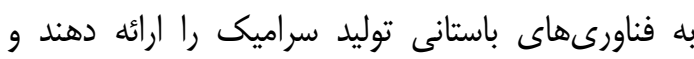
درك بهتر از روشهاى ساخت آنها را فراهم كنند. هدف از اين يزوهش، روشن ساختن سؤالات باستانشناسى در

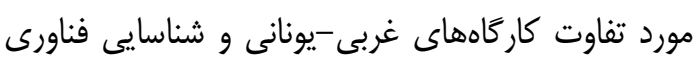
هاى مختلف ساخت در كلونىها است.

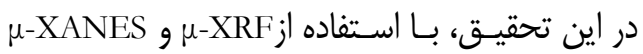

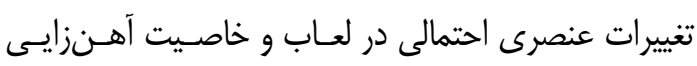

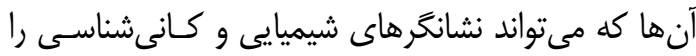

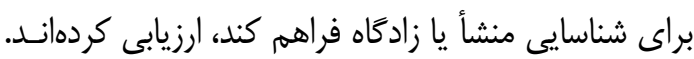

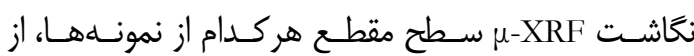

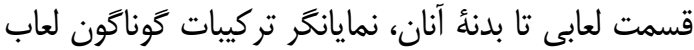
سياه در آنان است [37].

\section{• ( . سينكروترون و نياز مبرم كثور به آن} با توجه به قابليتهاى فراوان كشور عزيزمان ايران، نيـاز

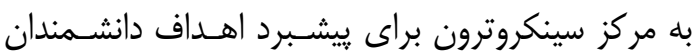


بلهورى كه اجزاى سازنده، عمر اثر، رديـابى بقايـاى اثر،

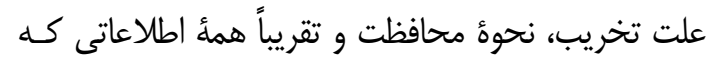

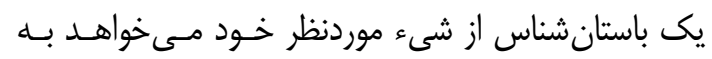

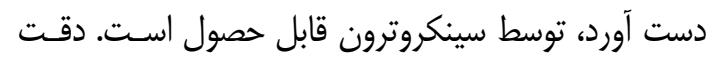

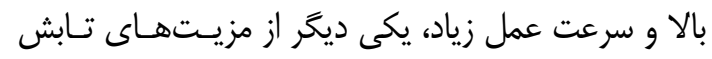

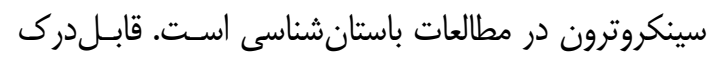

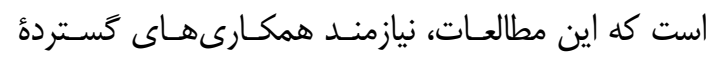

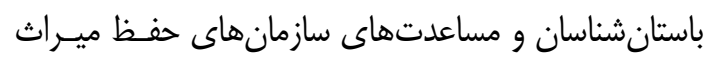

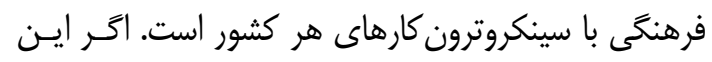

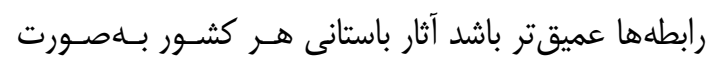

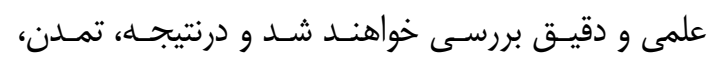

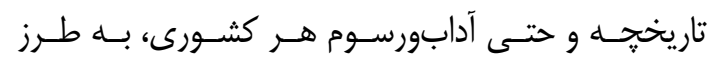
دقيقترى قابل ارزيابى خواهد بود. اين همكارى هابـا عـالاوه

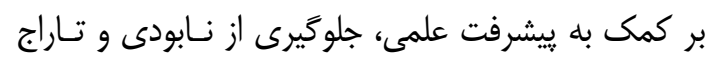
آثار باستانى را نيز فراهم خواهند ساخت.

\section{ي بيىنوشتها}

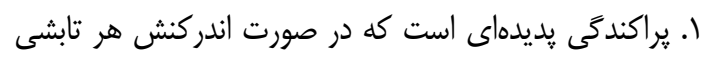

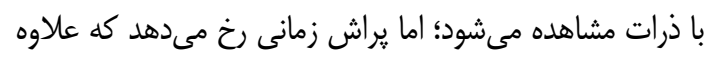

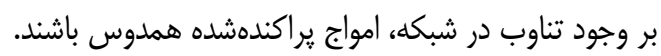

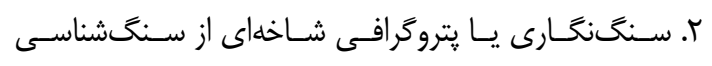

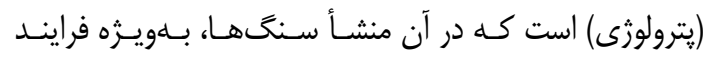
تشكيل آنها، موردمطالعُه علمى قرار مى خيرد.

\section{References}

[1] Seeck OH, Murphy B. X-ray Diffraction: Modern Experimental Techniques. Jenny Stanford Publishing; 2015 Feb 10.

[2] Winick H. Synchrotron radiation sources: a primer. World Scientific; 1995.

[3] Willmott P. An introduction to synchrotron radiation: techniques and applications. Wiley; 2019 Apr 29.

[4] Griffiths DJ. Introduction to electrodynamics.

[5] Eriksson M, Ahlbäck J, Andersson A, J ohansson M, Kumbaro D, Leemann SC, Lenngren C, Lilja P, Lindau F, Lindgren LJ, Malmgren L. The MAX IV synchrotron light source. THPC058, IPAC. 2011 Jan 1.

[6] Hofmann A. The physics of synchrotron
در حال ساخت نمونههايى از قطعات و تجهيزات شـتابحر هستند كه از آن جمله مىتوان بله تقويت كننده فر فركانس

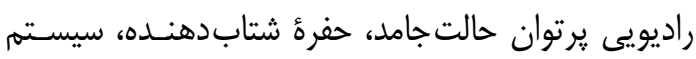

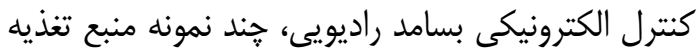

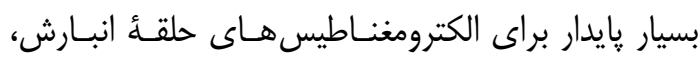

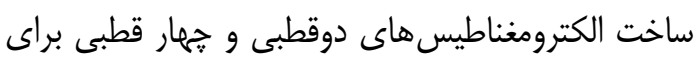

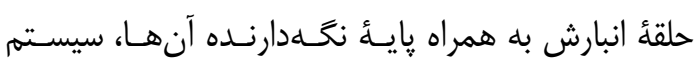

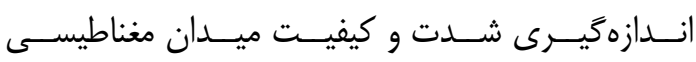

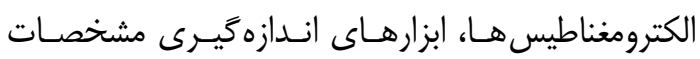

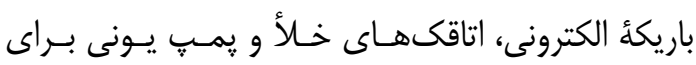

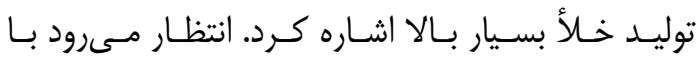

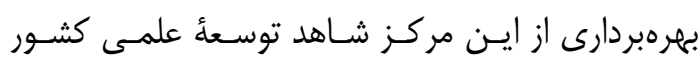

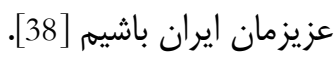

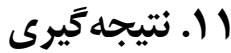

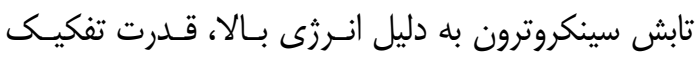

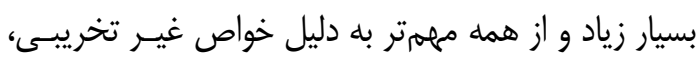

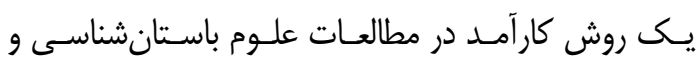

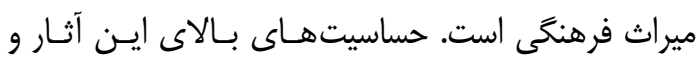

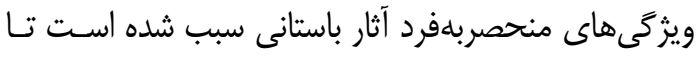

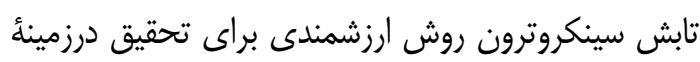

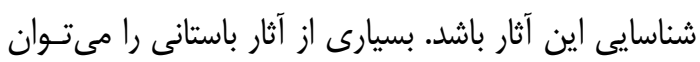

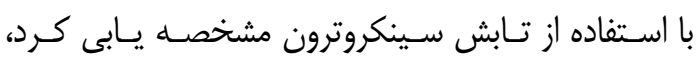

radiation. Cambridge University Press; 2004 May 13.

[7] Als-Nielsen J, McMorrow D. Elements of modern X-ray physics. John Wiley \& Sons; 2011 Apr 20.

[8] Bertrand L, Cotte M, Stampanoni M, Thoury M, Marone F, Schöder S. Development and trends in synchrotron studies of ancient and historical materials. Physics Reports. 2012 Oct 1;519(2):51-96.

[9] Schropp A, Boye P, Goldschmidt A, Hönig S, Hoppe R, Patommel J, Rakete C, Samberg D, Stephan S, Schöder S, Burghammer M. Non-destructive and quantitative imaging of a nano-structured microchip by ptychographic hard X-ray scanning microscopy. Journal of 
microscopy. 2011 Jan;241(1):9-12.

[10] Tuzikov FV, Zinoviev VV, Vavilin VI, Malygin EG. Application of the smallangle $\mathrm{x}$-ray scattering technique for the study of two-step equilibrium enzymesubstrate interactions. Biopolymers. 1996 Feb;38(2):131-9.

[11] Shackley MS. An introduction to X-ray fluorescence (XRF) analysis in archaeology. InX-ray fluorescence spectrometry (XRF) in geoarchaeology 2011 (pp. 7-44). Springer, New York, NY.

[12] Brouwer P. Theory of XRF. Almelo, Netherlands: PANalytical BV. 2006.

[13] Jalilehvand F. Keynote Lecture KN-01. Foundations of Crystallography. 2017;70:C5.

[14] Whitehead G, Crooks C. Department of Chemistry University of Calgary.

[15] Nelson RC, Miller JT. An introduction to $\mathrm{X}$-ray absorption spectroscopy and its in situ application to organometallic compounds and homogeneous catalysts. Catalysis Science \& Technology. 2012;2(3):461-70.

[16] Kalender WA. X-ray computed tomography. Physics in Medicine \& Biology. 2006 Jun 20;51(13):R29.

[17] Baruchel J, Buffiere JY, Maire E. X-ray tomography in material science.

[18] Cotte M, Checroun E, Mazel V, Solé VA, Richardin P, Taniguchi Y, Walter P, Susini J. Combination of FTIR and X-RAYS Synchrotron-Based Micro-Imaging Techniques for the Study of Ancient Paintings. A Practical Point of View. In8th international conference of the Infrared and Raman Users' Group 2009 (pp. 1-9).

[19] Salvado N, Butí S, Tobin MJ, Pantos E, Prag AJ, Pradell T. Advantages of the use of SR-FT-IR microspectroscopy: applications to cultural heritage. Analytical chemistry. 2005 Jun 1;77(11):3444-51.

[20] Cotte M, Dumas P, Taniguchi Y, Checroun E, Walter P, Susini J. Recent applications and current trends in Cultural Heritage Science using synchrotron-based Fourier transform infrared microspectroscopy. Comptes Rendus Physique. 2009 Sep 1;10(7):590-600.

[21] Sánchez del Rio M, Martinetto P, ReyesValerio C, Dooryhee E, Suárez M. Synthesis and acid resistance of Maya Blue pigment. Archaeometry. 2006 Feb;48(1):115-30.

[22] Cotte M, Susini J, Dik J, Janssens K. Synchrotron-based X-ray absorption spectroscopy for art conservation: looking back and looking forward. Accounts of chemical research. 2010 Jan 8;43(6):705-14.

[23] Quartieri S. Synchrotron Radiation in Art, Archaelogy and Cultural Heritage. InSynchrotron Radiation 2015 (pp. 677695). Springer, Berlin, Heidelberg.

[24] Nakai I. Matsunaga M. Adachi M. Hidaka K. I. J. Phys. IV, 7 (1997) 1033-1034.

[25] Bertrand L, Doucet J, Dumas P, Simionovici A, Tsoucaris G, Walter P. Microbeam synchrotron imaging of hairs from ancient Egyptian mummies. Journal of synchrotron radiation. 2003 Sep 1;10(5):387-92.

[26] Bertrand L, Doucet J, Dumas P, Simionovici A, Tsoucaris G, Walter P. Microbeam synchrotron imaging of hairs from ancient Egyptian mummies. Journal of synchrotron radiation. 2003 Sep 1;10(5):387-92. Bertrand L, Doucet J, Dumas P, Simionovici A, Tsoucaris G, Walter P. Microbeam synchrotron imaging of hairs from ancient Egyptian mummies. Journal of Synchrotron Radiation. 2003 Sep 1;10(5):387-92.

[27] Hiller JC, Wess TJ. The use of small-angle $\mathrm{X}$-ray scattering to study archaeological and experimentally altered bone. Journal of archaeological Science. 2006;33(4):560-72.

[28] Creagh DC, Bradley D. Physical techniques in the study of art, archaeology and cultural heritage. Elsevier; 2007 Jul 6.

[29] Shoval S. Fourier transform infrared spectroscopy (FT-IR) in archaeological ceramic analysis. InThe Oxford Handbook of Archaeological Ceramic Analysis 2017.

[30] Sandström M, Fors Y, Persson I. The Vasa's New Battle: Sulfur, Acid and Iron. National Maritime Museums [Statens maritima museer]; 2003.

[31] Creagh DC, Bradley D. Physical techniques in the study of art, archaeology and cultural heritage. Elsevier; 2007 Jul 6.

[32] Sandström M, Jalilehvand F, Persson I, Gelius U, Frank P, Hall-Roth I. Deterioration of the seventeenth-century warship Vasa by internal formation of sulphuric acid. Nature. 2002 Feb;415(6874):893. 
[33] Creagh DC, Bradley D. Physical techniques in the study of art, archaeology and cultural heritage. Elsevier; 2007 Jul 6.

[34] Morigi MP, Casali F, Bettuzzi M, Brancaccio R, d'Errico V. Application of $\mathrm{X}$-ray computed tomography to cultural heritage diagnostics. Applied Physics A. 2010 Sep 1;100(3):653-61.

[35] Rigon L, Vallazza E, Arfelli F, Longo R, Dreossi D, Bergamaschi A, Schmitt B, Chen R, Cova MA, Perabò R, Fioravanti M. Synchrotron-radiation microtomography for the non-destructive structural evaluation of bowed stringed instruments. e-Preservation Science. 2010;7:71-7.

https://www.albasynchrotron.es/en/medi a/news/prehistoric-iranian-glass-under- synchrotron-light.

[36] Gianoncelli A, Raneri S, Schoeder S, Okbinoglu T, Barone G, Santostefano A, Mazzoleni P. nSynchrotron $\mu$-XRF imaging and $\mu$-XANES of black-glazed wares at the PUMA beamline: insights on technological markers for colonial productions. Microchemical Journal. 2020 Jan 13:104629.

[37] Rahighi J, Ghasem H, Jafarzadeh M, Sarhadi K, Dehghani J, Khosroabadi H, Yousefi E, Sadeghipanah A, Saeidi F, Fatehi S, Ahmadi E. ILSF, a third generation light source laboratory in Iran. Proceedings of IPAC2013, Shanghai, China, TUOAB202. 2013 May 12. 